\title{
Oea
}

JURNAL PENDIDIKAN GEOGRAFI

\section{PEMANFAATAN LINGKUNGAN SEKITAR SEBAGAI SUMBER PEMBELAJARAN IPS UNTUK MENINGKATKAN KEMAMPUAN BERPIKIR KRITIS}

\author{
${ }^{1}$ Isye Ramawati, SMPN 52 Bandung, email: isyeramawati22@gmail.com \\ ${ }^{2}$ Enok Maryani, Jurusan Pendidikan Geografi FPIPS-UPI, e-mail: emaryani@ yahoo.com \\ ${ }^{3}$ Agus Mulyana, Jurusan Pendidikan Sejarah, e-mail:
}

\begin{abstract}
ABSTRAK
Fokus pada penelitian ini adalah pemanfaatan lingkungan sekitar sekolah sebagai sumber belajar efektif dan efisien untuk meningkatkan berpikir kritis peserta didik dalam pembelajaran IPS. Melalui metode inkuiri peserta didik diharapkan mampu berpikir kritis yang di dalamnya terdapat indikator-indikator : orientasi pada masalah, belajar meneliti, pemecahan masalah, mengembangkan dan menyajikan hasil pemecahan masalah dan menganalisa proses pemecahan masalah melalui proses pengamatan lingkungan yaitu Kawasan Punclut yang merupakan kawasan yang terletak di Bandung Utara, kawasan ini merupakan bagian dari cekungan Bandung yang memiliki kondisi alam dan keterkaitan ekosistem yang sangat penting untuk menjadi kawasan hutan lindung, dan sebagai salah satu generator iklim mikro serta entry point bagi penataan kawasan Bandung Utara, dimana indikator yang diteliti adalah vegetasi, kemiringan lereng, pola penggunaan lahan dan kedalaman air tanah (dilihat dari kedalaman sumur gali). Subjek penelitian adalah peserta didik kelas VII SMPN 52 Bandung tahun ajaran 2012-2013. Metode penelitian yang dipakai adalah kuasi eksperimen dengan instrument penelitian berupa pedoman observasi lapangan, observasi kelas, tes berpikir kritis, dan wawancara guru dan peserta didik. Hasil penelitian menunjukkan terdapat perbedaan yang signifikan antara hasil pretest dan posttest berpikir kritis pada kelas yang memanfaatkan lingkungan sekitar sebagai sumber belajar melalui metode inkuiri dengan yang tidak memanfaatkan lingkungan sekitar sebagai sumber belajar melalui metode ceramah. Hal ini terlihat dari uji t yang menunjukkan bahwa kemampuan peserta didik yang memanfaatkan lingkungan sekitar sebagai sumber belajar melalui metode inkuiri dengan peserta didik yang tidak memanfaatkan lingkungan sekitar sebagai sumber belajar dengan menggunakan metode ceramah adalah berbeda secara signifikan. Dengan demikian, pemanfaatan lingkungan sekitar sebagai sumber belajar dapat meningkatkan cara berpikir kritis peserta didik. Rekomendasi yang dapat disampaikan : 1) Dibutuhkan kepiawaian guru untuk merancang perencanaan pembelajaran yang sesuai dengan tujuan pembelajaran dan lingkungan yang berada di sekitar sekolah. 2) Sebelum peserta didik memanfaatkan lingkungan sekitarnya, hendaknya mereka dibekali wawasan keilmuan dan hubungan sosial dengan masyarakat sebagai landasan dasar berpikir kritis.
\end{abstract}

Kata Kunci : Pemanfaatan lingkungan, sumber belajar IPS, berpikir kritis, metode inkuiri

\section{PENDAHULUAN}

Sesuai UUSPN No 20 tahun 2003, menyatakan bahwa pendidikan nasional berfungsi mengembangkan kemampuan dan membentuk warga serta peradaban bangsa yang bermartabat dalam rangka mencerdaskan kehidupan bangsa, yang bertujuan untuk berkembangnya potensi peserta didik agar menjadi manusia yang beriman dan bertakwa kepada Tuhan YME, berahlak 
mulia, sehat, berilmu, cakap, kreatif, mandiri dan menjadi warga yang demokratis dan bertanggung jawab. Pada akhirnya pendidikan adalah upaya untuk mewujudkan sebuah masyarakat yang ditandai adanya keluhuran budi dalam tiap individu, keadilan dalam negara, dan kehidupan yang lebih bahagia.

Untuk mewujudkan cita-cita UUSPN, diperlukan kerja keras antar berbagai komponen yang mendukung kegiatan pendidikan, banyak kendala yang dihadapi salah satunya adalah kualitas guru yang masih rendah. Secara umum, kualitas guru dan kompetensi guru di Indonesia masih belum sesuai dengan yang diharapkan. Menurut data kompas tanggal 3 Juli tahun 2012, dari sisi kualifikasi pendidikan hingga saat ini, dari 2,92 juta guru baru sekitar 51 persen yang berpendidikan S-1 atau lebih, sedangkan sisanya belum berpendidikan S-1. Begitu pun dari persyaratan sertifikasi, hanya 2,06 juta guru atau sekitar 70,5 persen guru yang memenuhi syarat sertifikasi, adapun 861.67 guru lainnya belum memenuhi syarat sertifikasi. Selain jenjang pendidikan yang belum memadai, kompetensi guru juga masih bermasalah. Saat dilakukan tes terhadap guru semua bidang studi, rata-rata tak sampai 50 persen soal yang dapat dikerjakan. Tidak ada guru yang meraih nilai 80 . Bahkan, ada guru yang meraih nilai terendah yaitu nilai 1.

Pernyataan di atas merupakan salah satu permasalahan dalam praktik-praktik pendidikan yang mengakibatkan mutu pendidikan di Indonesia menurun. Keberadaan guru sebagai ujung tombak pendidikan, guru sebagai praktisi pendidikan seharusnya memiliki kompetensi dalam menunjukkan keprofesionalannya. Tuntutan guru masa depan hendaknya menjadikan dirinya sebagai fasilitator bagi peserta didik dalam menempuh pengalaman belajarnya, sehingga peserta didik dapat mengeluarkan seluruh potensinya.

Asa Hilliard III (Arcaro, 1997:40) bahwa, "Teachers are the mediators who provide or fail to provide the essential experiences that permit student to release their all potentials". Karena itu, guru harus menghindari model pendidikan "gaya bank" dimana siswa hanya mampu bergerak dalam tiga hal, yaitu mencatat - menerima - menyimpan. Dalam hal ini, guru hendaknya senantiasa menciptakan atmosfer pembelajaran kreatif, menyenangkan, dan penuh makna (meaningfull learning). Berdasarkan Permen nomor 22 tahun 2006, mata pelajaran IPS khususnya di Sekolah Menengah Pertama mengacu pada Standar Kompetensi dan Kompetensi Dasar yang bertujuan agar peserta didik memiliki kemampuan sebagai berikut :

(1) Mengenal konsep-konsep yang berkaitan dengan kehidupan masyarakat dan lingkungan.

(2) Memiliki kemampuan dasar untuk berpikir logis dan kritis, rasa ingin tahu, inkuiri, memecahkan masalah, dan keterampilan dalam kehidupan sosial.

(3) Memiliki komitmen dan kesadaran terhadap nilai-nilai sosial dan kemanusiaan

(4) Memiliki kemampuan berkomunikasi, bekerjasama dan berkompetisi dalam masyarakat yang majemuk, di tingkat lokal, nasional, dan global.

Pada kompetensi point 2 yaitu berpikir logis dan kritis, rasa ingin tahu, inkuiri, memecahkan masalah, dan keterampilan dalam kehidupan sosial, hendaknya peserta didik dilibatkan ke dalam suasana kehidupan yang nyata yang penuh dengan persoalan yang harus diteliti dan dipikirkan secara kritis. Peserta didik dilatih untuk membuat suatu keputusan tentang hal-hal yang berkenaan dengan kebijakan dan kehidupan demokrasi, harus mampu mengelola dirinya sendiri, dan mampu berlaku dan bertindak sebagai anggota masyarakat.

Hasan (1996:12), bahwa kemampuan bukan saja berhubungan dengan disiplin sosial tertentu, tetapi juga dapat berupa kemampuan yang bersifat umum dalam menghadapi masalah sehari-hari, seorang peserta didik dalam kenyataan kehidupan sehari-haripun tidak terlepas dari keharusan membuat berbagai macam keputusan. Salah satu kemampuan yang harus dimiliki peserta didik yaitu berpikir kritis. Berpikir kritis menurut Dewey (Fisher, 2008 :2) adalah pertimbangan yang aktif, persistent (terus menerus), dan teliti mengenai sebuah keyakinan atau 
bentuk pengetahuan yang diterima begitu saja dipandang dari sudut alasan-alasan yang mendukungnya dan kesimpulan-kesimpulan lanjutan yang menjadi kecenderungannya.

Glaser (Fisher, 2008 : 3) menyatakan bahwa berpikir kritis sebagai: 1) suatu sikap mau berpikir secara mendalam tentang masalah-masalah dan hal-hal yang berada dalam jangkauan pengalaman seseorang; 2) Pengetahuan tentang metode-metode pemeriksaan dan penalaran yang logis; dan 3) Semacam suatu keterampilan untuk menerapkan metode-metode tersebut. Berpikir kritis menuntut upaya keras untuk memeriksa setiap keyakinan atau pengetahuan asumtif berdasarkan bukti pendukungnya dan kesimpulan-kesimpulan lanjutan yang diakibatkannya.

Tujuan berpikir kritis menurut Sapriya (2009:87) ialah untuk menguji suatu pendapat atau ide, termasuk di dalam proses ini adalah melakukan pertimbangan atau pemikiran yang didasarkan pada pendapat yang diajukan. Pertimbangan-pertimbangan itu biasanya didukung kriteria yang dapat dipertanggungjawabkan. Berpikir kritis sangat diperlukan oleh setiap individu untuk menyikapi permasalahan hidup dan kehidupan yang dihadapi, dengan kemampuan berpikir kritis seseorang dapat mengelola, mengatur, menyesuaikan, mengubah atau memperbaiki pikirannya, sehingga dia dapat bertindak benar dan lebih tepat. Berpikir kritis harus terus dikembangkan kepada peserta didik sebagai tujuan utama pendidikan.

Dunn and Dunn (Sapriya, 2009:87) membagi berpikir kritis dalam beberapa langkah :

(1) Guru menentukan fokus atau topik pokok bahasan yang dapat mendorong siswa berpikir.

(2) Guru mengajukan pertanyaan berikutnya, mengapa ide ini belum diterapkan (hal-hal yang apakah yang menghambat untuk melakukan perbuatan tersebut). (3) Setelah para siswa menjawab pertanyaan ini dan merencanakan membantu siswa berpikir tentang yang mungkin dilakukan dengan mengatasi suatu hambatan, guru bertanya bagaimana cara mengatasi kesulitan-kesulitan tersebut.(4) Guru meminta siswa agar memberikan alternatif/kemungkinan jawaban-jawaban itu dapat diterapkan terhadap masalah sebelumnya. (5) Siswa diminta untuk mengambil keputusan apakah seharusnya menjadi langkah pertama dalam memecahkan suatu masalah.

Individu yang berfikir kritis biasanya memperlihatkan ciri-ciri seperti dikemukakan Costa (1985 :277), yaitu :

Pandai mendeteksi permasalahan, mampu mengidentifikasi perbedaan dan informasi, mengumpulkan data untuk pembuktian, mampu mengidentifikasi, mampu mendaftar alternatif pemecahan masalah dengan masalah lainnya, mampu membuat hubungan yang berurutan antara satu masalah dengan masalah lainnya, mampu menarik kesimpulan yang tersedia yang diperoleh dari lapangan, mampu membuat prediksi dari informasi yang tersedia, mampu menarik kesimpulan dari data yang telah ada dan terseleksi dan mampu mengklasifikasikan informasi serta ide.

Penerapan berpikir kritis dapat diaplikasikan ke dalam pokok-pokok bahasan IPS yang digali dari permasalahan sehari-hari, yang merupakan materi yang baik dan layak untuk didiskusikan di dalam kelas. Persoalan-persoalan dapat dibahas peserta didik dibawah bimbingan guru untuk mengungkapkan penyebab, akibat dan bagaimana pemecahannya. Secara krtitis dan tajam, peserta didik dilatih mengidentifikasikan masalahnya, membuat perkiraan tentang relasi berbagai aspek sosial yang merupakan sebab-akibat masalah, mencoba mengumpulkan atau menggali informasi berkenaan dengan masalah tadi, dan akhirnya mereka dilatih menyusun alternatif solusi atau pemecahan masalah tadi. Pada kenyataannya, selama ini pendidikan IPS banyak mendapatkan hambatan dalam perkembangannya. Berdasarkan pengamatan secara langsung banyak permasalahan yang dihadapi di lapangan, diantaranya kurang berminatnya peserta didik dalam mempelajari ilmu-ilmu sosial merupakan suatu bukti kemunduran IPS. Berbagai masalah dalam IPS yang dianggap sebagai mata pelajaran yang membosankan sehingga kurang merangsang peserta didik untuk berpikir kritis dan kurang mampu untuk mengatasi masalah, peserta didik tidak dilibatkan dalam proses pembelajaran, 
pembelajaran didominasi oleh guru (teacher centered), penggunaan media pembelajaran yang kurang menarik, metode pembelajaran yang monoton, guru belum memanfaatkan lingkungan sebagai media serta sumber belajar yang menarik dan hanya buku paket yang dijadikan sumber belajar.

Masalah-masalah tersebut sering terjadi pula dalam proses pembelajaran di SMPN 52 Bandung, dimana antusiasme peserta didik dalam belajar rendah, terlihat dari peserta didik yang kurang bersemangat untuk mengikuti mata pelajaran IPS, sehingga siswa menjadi tidak aktif dan terlihat bosan. Gejala-gejala tersebut ditunjukkan dengan beberapa sikap seperti acuh tak acuh, kurang menyimak materi yang sedang disampaikan dan sering keluar masuk kelas. Dalam hal penyampaian materi, guru yang seringkali melakukan pembelajaran teksbook dan ceramah, sehingga tidak merangsang peserta didik untuk berpikir kritis serta kurang terjalin interaksi antara guru dengan peserta didik dan peserta didik dengan peserta didik lainnya. Sikap masa bodoh terhadap materi yang disampaikan oleh guru, sehingga ketika guru bertanya atau menyuruh peserta didik untuk bertanya mengenai apa yang sedang dibahas, sebagian besar peserta didik bersikap pasif. Bila guru bertanya kadang peserta didik menjawab dengan asal, tanpa didukung oleh teori dan argumen yang baik, serta lingkungan belajar yang kaku dan membosankan dalam proses kegiatan pembelajaran.

Ketika pembelajaran berlangsung dan guru memakai metode ekspositori (ceramah) kebanyakan peserta didik kurang aktif, kurang memiliki motivasi dan hasil belajar rata-rata kelasnya kurang dari Kriteria Ketuntasan Minimal (KKM). Dari data buku KTSP dokumen 1 SMPN 52 Bandung, KKM tahun ajaran 2012-2013 mata pelajaran IPS untuk kelas 7 adalah 70, dengan rata-rata nilai UAS semester 1 adalah 60,79 untuk kelas $8 \mathrm{KKM}$ mata pelajaran IPS adalah 73 dengan rata-rata nilai UAS semester 1 adalah 60,40 sedangkan untuk kelas 9 KKM mata pelajaran IPS adalah 73, dengan rata-rata nilai UAS semester 1 adalah 60,10. Hal ini memberikan suatu indikasi terhadap suatu masalah yang cukup signifikan yaitu permasalahan yang bermuara pada kejenuhan siswa dalam mengikuti pembelajaran IPS, yang berimbas pada rendahnya prestasi hasil belajar siswa dalam mata pelajaran IPS. Selain faktor peserta didik, faktor guru juga memberi kontribusi dalam permasalahan, sebagian besar guru-guru IPS di SMPN 52 Bandung masih menggunakan metode ekspositori atau ceramah, penggunaan alatalat peraga masih minim dipergunakan dan guru-guru belum memanfaatkan lingkungan sekitar sebagai sumber belajar secara optimal. Permasalahan lain yang dialami peserta didik di SMPN 52 Bandung adalah belum terbiasa berpikir secara kritis dalam menghadapi dan memecahkan suatu masalah, dan salah satu cara untuk mengembangkan peserta didik untuk berpikir kritis adalah mengaplikasikan melalui penggunaan berbagai metode dan sumber belajar. Pengertian metode pembelajaran menurut Maryani (2011 : 33), diartikan sebagai cara yang dipergunakan untuk mencapai tujuan atau maksud. Metode sangat diperlukan oleh guru bukan hanya untuk menyampaikan sejumlah materi, tetapi yang lebih penting agar kompetensi pendidikan dapat dicapai. Tidak hanya metode pembelajaran, sumber belajar juga sangat berpengaruh penting dalam proses kegiatan belajar mengajar. Salah satu definisi sumber belajar menurut AECT adalah sebagai berikut: "Sumber belajar adalah semua sumber baik berupa data, orang, dan wujud tertentu yang dapat digunakan oleh siswa dalam belajar, baik secara terpisah maupun secara terkombinasi sehingga mempermudah siswa dalam mencapai tujuan belajarnya" (AECT,1977).

Ehlirch \& Ehlirch dan Holdren (1973 : 4) mengemukakan :

"The environment is the unique skin of soil, water, geseous atmosphere, mineral nutrients, and organisms that covers this otherwise undistinguished planet". Menurut Miller (1985 : 34-35) mengemukakan: "The living things is a nature community are surrounded by an environment concisting of other living plants and animals, called the biotic portion, and nonliving or nonbiotic portion concisting of chemicals and physical factors such as solar energy, temperature, ligh, wind, and water currents". 
Lingkungan sebagai sumber belajar dapat dimaknai sebagai segala sesuatu yang ada di sekitar atau di sekeliling siswa (makhluk hidup lain, benda mati, dan budaya manusia) yang dapat dimanfaatkan untuk menunjang kegiatan belajar dan pembelajaran secara lebih optimal. Dalam hal ini lingkungan alam sebagai sumber belajar menurut Komalasari (2010:124) mencakup aspek alamiah seperti air, hutan, tanah, udara, matahari, batuan, tanah, flora, fauna, sungai, danau dan sebagainya. Pemanfaatan lingkungan alam (fisik) sebagai sumber belajar dapat dilakukan dalam rangka mengembangkan potensi peserta didik untuk melakukan kegiatan di luar kelas dan menemukan sebab-sebab sebuah kejadian di sekitarnya, serta mencari hubungan antara fakta-fakta yang ada di lingkungan alam. Dengan memanfaatkan lingkungan sebagai sumber belajar maka hal itu akan lebih bermakna dan bernilai, sebab para peserta didik diharapkan lebih memahami peristiwa dan keadaan yang sebenarnya, keadaan yang dialami peserta didik lebih nyata, lebih faktual, dan kebenarannya lebih dapat dipertanggungjawabkan. Dengan kata lain dengan memanfaatkan lingkungan sebagai sumber belajar, dapat diperoleh tujuan karena lingkungan menyediakan berbagai hal yang dapat dipelajari peserta didik, dapat memperkaya wawasannya, tidak terbatas oleh dinding kelas, dan kebenarannya lebih akurat. Kegiatan belajar dimungkinkan akan lebih menarik, tidak membosankan, dan menumbuhkan antusiasme peserta didik untuk lebih giat belajar. Belajar akan lebih bermakna (meaningful learning), sebab peserta didik diharapkan dengan keadaan yang sebenarnya. Aktifitas peserta didik akan lebih meningkat dengan memungkinkannya menggunakan wawancara, membuktikan sesuatu, dan menguji fakta. Dengan memahami dan menghayati aspek-aspek kehidupan yang ada di lingkungannya, dapat dimungkinkan terjadinya pembentukan pribadi para peserta didik, seperti cinta akan lingkungan.

Salah satu strategi mengajar yang tepat dalam pemanfaatan lingkungan sebagai sumber belajar adalah dengan metode inkuiri. Penggunaan metode inkuiri sebagai upaya untuk menciptakan suasana pembelajaran yang kondusif dan menyenangkan dengan mengacu kepada minat peserta didik dengan mengangkat isu-isu yang sedang hangat di masyarakat dan menciptakan peserta didik berpikir kritis dan sistematis (Wena, 2009:71). Melalui pemusatan pembelajaran dengan menggunakan metode inkuiri ini diharapkan siswa dapat meningkat motivasi belajarnya dan lebih berprestasi sehingga mampu memecahkan masalah atau isu-isu yang sedang hangat dalam lingkungan sekolah atau masyarakat secara relevan. Dengan penerapan metode inkuiri ini diharapkan dapat dijadikan sebagai salah satu upaya yang dapat dilakukan oleh guru untuk meningkatkan kompetensi dasar peserta didik di dalam aspek kognitif, afektif dan psikomotorik. Alasan rasional penggunaan metode inkuiri adalah bahwa peserta didik akan mendapatkan pemahaman yang lebih baik mengenai suatu bidang ilmu dan akan lebih tertarik terhadap bidang ilmu itu jika mereka dilibatkan secara aktif dalam proses pembelajaran. Investigasi yang dilakukan oleh peserta didik merupakan tulang punggung metode inkuiri. Investigasi ini difokuskan untuk memahami konsep-konsep suatu bidang ilmu dan meningkatkan keterampilan proses berpikir ilmiah siswa. Diyakini bahwa pemahaman konsep merupakan hasil dari proses berpikir ilmiah tersebut. (Blosser, 1990).

Agar penelitian ini lebih terarah, maka dirumuskan beberapa sub masalah sebagai berikut: 1) Apakah terdapat perbedaan antara hasil pretest dan posttest kemampuan berpikir kritis pada peserta didik dengan memanfaatkan lingkungan sebagai sumber belajar pada kelas eksperimen melalui metode inkuiri ?; 2) Apakah terdapat perbedaan antara hasil pretest dan posttest pada kemampuan berpikir kritis peserta didik yang tidak memanfaatkan lingkungan sebagai sumber belajar pada kelas kontrol dengan menggunakan metode ceramah?; 3) Apakah terdapat perbedaan kemampuan berpikir kritis peserta didik yang memanfaatkan lingkungan sekitar sebagai sumber belajar melalui metode inkuiri dengan yang tidak memanfaatkan lingkungan sebagai sumber belajar dan menggunakan metode ceramah?; 4) Bagaimana respon peserta didik setelah memanfaatkan lingkungan sebagai sumber belajar dengan menggunakan 
metode inkuiri dan apa saja kendala yang dihadapi guru dalam meningkatkan cara berpikir kritis peserta didik dengan memanfaatkan lingkungan sebagai sumber belajar?

Tujuan penelitian adalah: 1) Mengetahui perbedaan pretest dan posttest kemampuan berpikir kritis peserta didik dengan memanfaatkan lingkungan sebagai sumber belajar pada kelas eksperimen dengan menggunakan metode inkuiri; 2) Mengetahui perbedaan pretest dan posttest kemampuan berpikir peserta didik yang tidak memanfaatkan lingkungan sebagai sumber belajar pada kelas kontrol dengan menggunakan metode ceramah; 3) Mengetahui perbedaan cara berpikir kritis kemampuan berpikir kritis peserta didik yang memanfaatkan lingkungan sekitar sebagai sumber belajar melalui metode inkuiri dengan yang tidak memanfaatkan lingkungan sebagai sumber belajar dan menggunakan metode ceramah?; 4) Mengetahui respon peserta didik setelah memanfaatkan lingkungan sebagai sumber belajar dengan menggunakan metode inkuiri dan kendala apa saja yang dihadapi guru dalam meningkatkan cara berpikir kritis peserta didik dengan memanfaatkan lingkungan sebagai sumber belajar.

\section{METODE PENELITIAN}

Penelitian ini menggunakan metode kuasi eksperimen, yaitu menggunakan satu percobaan yang dirancang secara khusus guna membangkitkan data yang diperlukan untuk menjawab pertanyaan penelitian. Subjek penelitian eksperimen dibagi ke dalam dua kelompok sasaran penelitian. Satu kelompok diberi perlakuan khusus tertentu dan satu kelompok lagi dikendalikan pada satu keadaan yang pengaruhnva dijadikan sebagai suatu pembanding, yang disebut kelompok kontrol. Kelompok eksperimen dikenakan perlakuan dengan metode inkuiri, sedangkan kelompok kontrol menggunakan metode ceramah. Disain penelitian yang digunakan adalah nonequivalent (pretest and posttest control group design), kelompok eksperimen dan kelompok kontrol diseleksi tanpa penetapan secara random, kedua kelompok memperoleh pretest dan post test dan hanya kelompok eksperimen yang menerima perlakuan. Pretest untuk mengukur penguasaan konsep dan kemampuan berfikir kritis dengan menggunakan metode inquiry sebelum perlakuan pada kelompok eksperimen dan kelompok kontrol. Posttest untuk mengukur penguasaan konsep dan kemampuan berfikir kritis dengan menggunakan metode inquiry setelah perlakuan pada kelompok eksperimen dan kelompok kontrol. Perlakuan dengan memanfaatkan lingkungan sekitar melalui metode inkuiri dan Perlakuan dengan menggunakan metode penugasan. Penelitian dilakukan dalam tiga kali pertemuan pembelajaran, dengan satu kali pretest dan satu kali posttest, yang dilaksanakan pada semester genap tahun pelajaran 2012 -2013. Setiap pertemuan menggunakan waktu $2 \mathrm{x}$ 40 menit.

Populasi dalam penelitian ini adalah peserta didik kelas VII di SMPN 52 Bandung tahun pelajaran 2012-2013, yang terdiri dari 10 kelas. Penggambilan sampel dalam penelitian ini menggunakan teknik simple random sampling. Dari 10 kelas yang ada diambil secara acak yaitu kelas 7-1 sebagai sampel kelas eksperimen dan kelas 7-2 sebagai kelas kontrol.

\section{HASIL DAN PEMBAHASAN}

Bab ini akan membahas dan menguraikan hasil penelitian yang didasarkan pada tujuan penelitian yang telah dirumuskan pada bab I. Data penelitian di peroleh dari hasil pretest dan posttest baik pada kelompok eksperimen maupun kelompok kontrol, observasi di lapangan dan di dalam kelas, serta hasil wawancara yang dilakukan terhadap beberapa orang guru dan peserta didik . Data observasi lapangan di dapat dengan pengamatan langsung yang dilakukan kelompok eksperimen di kawasan Punclut. Hasil wawancara guru dan peserta didik untuk melihat tentang pemanfaatan lingkungan sekitar (kawasan Punclut) sebagai sumber belajar dan tanggapan berpikir kritis, data observasi di kelas berkenaan dengan implementasi berpikir kritis, sedangkan hasil belajar diperoleh dengan melihat pretest dan posttest pada kelompok 
kontrol maupun kelompok eksperimen untuk melihat ada tidaknya perkembangan dalam proses pembelajaran yang dibuat dalam hasil belajar atau nilai.

\section{A. Deskripsi Umum}

\section{Subjek Penelitian}

SMP Negeri 52 merupakan salah satu SMP Negeri yang ada di Kota Bandung, didirikan pada bulan Juli tahun 2000 yang merupakan kelas jauh dari SMP Negeri 15 Bandung. Sebelum memiliki gedung sendiri SMP Negeri 52 menggunakan SD Negeri Bandung Baru. Pada tanggal 15 September 2004 diresmikanlah gedung baru SMP Negeri 52 Bandung yang berlokasi di J1 Bukit Raya Ciumbuleuit Punclut Bandung.

Hingga saat ini SMP Negeri 52 Bandung memiliki 31 rombongan belajar, dengan kriteria sebagai berikut: kelas VII sebanyak 10 rombongan belajar, kelas VIII sebanyak 11 rombongan belajar, dan kelas IX sebanyak 10 rombongan belajar.

\section{Keadaan kelas VII}

Di kelas VII terdapat 10 rombongan belajar, dua kelas menjadi sampel penelitian yakni kelas VII-1 sebagai kelas eksperimen dan kelas VII-2 sebagai kelas kontrol. Perbandingan komposisi kelas tersebut dapat dilihat pada tabel 4.1 :

Tabel 4.1 Komposisi Peserta Didik Kelas VII SMP Negeri 52 Bandung Semester Genap Tahun Pelajaran 2012-2013

\begin{tabular}{|c|c|c|c|}
\hline \multirow{2}{*}{ Kelas } & \multirow{2}{*}{ Jumlah siswa } & \multicolumn{3}{|c|}{ Jenis Kelamin } \\
\cline { 3 - 4 } & 36 & Laki-laki & Perempuan \\
\hline VII- 1 & 36 & 18 & 18 \\
\hline VII- & 36 & 18 & 18 \\
\hline VII- & 35 & 17 & 18 \\
\hline VII- & 34 & 16 & 18 \\
\hline VII- 5 & 36 & 18 & 18 \\
\hline VII- 6 & 35 & 17 & 17 \\
\hline VII- -7 & 34 & 17 & 17 \\
\hline VII-8 & 33 & 16 & 22 \\
\hline VII-9 & 36 & 18 & 18 \\
\hline VII-10 & 34 & 12 & \\
\hline Sun
\end{tabular}

Sumber : Buku KTSP SMPN 52 Bandung

Selanjutnya sebagai perbandingan rata-rata nilai mata pelajaran IPS di kelas VII pada semester ganjil tahun pelajaran 2012-2013 dapat dilihat pada tabel berikut :

Tabel 4.2 Rata-rata Nilai IPS Kelas VII SMPN 52 Bandung Semester Ganjil Tahun Pelajaran 2012-2013

\begin{tabular}{|c|c|c|}
\hline Kelas & KKM & Nilai \\
\hline VII- 1 & 70 & 65 \\
\hline VII- 2 & 70 & 65 \\
\hline VII- 3 & 70 & 63 \\
\hline VII- 4 & 70 & 64 \\
\hline VII- 5 & 70 & 66 \\
\hline VII- 6 & 70 & 69 \\
\hline VII- 7 & 70 & 67 \\
\hline VII-8 & 70 & 68 \\
\hline VII-9 & 70 & 62 \\
\hline VII -10 & 70 & 60 \\
\hline
\end{tabular}

Sumber : Buku KTSP SMPN 52 Bandung 
Jika dilihat dari komposisi kelas dan nilai rata-rata mata pelajaran IPS di kelas VII-1 dan kelas VII-2 mempunyai perbandingan yang relatif tidak jauh berbeda sehingga kedua kelas ini layak untuk dijadikan subjek penelitian.

\section{Deskripsi Hasil Penelitian}

3.1 Deskripsi Kelas Eksperimen

1) Hasil Pretest Kelas Eksperimen

Pretest diberikan pada kelas eksperimen sebelum pembelajaran dengan metode inkuiri dilaksanakan. Jumlah butir soal adalah 30, yang terdiri dari 25 butir soal berbentuk pilihan ganda dan 5 butir soal berbentuk uraian. Data pretest disajikan pada tabel 4.3 di halaman berikutnya.

Tabel 4.3

Data Pretest Kelas Eksperimen

Pretest
\begin{tabular}{|l|r|}
\hline \multicolumn{1}{|c|}{ Valid $\quad$ Missing } & 36 \\
Mean & 0 \\
Std. Error of Mean & 39.19 \\
Median & 1.529 \\
Mode & 40.00 \\
Std. Deviation & 40 \\
Variance & 9.174 \\
Skewness & 84.161 \\
Std. Error of Skewness & .176 \\
Kurtosis & .393 \\
Std. Error of Kurtosis & -.289 \\
Range & .768 \\
Minimum & 40 \\
Maximum & 20 \\
\hline
\end{tabular}

Sumber : Hasil pengolahan data, 2013

Dari tabel 4.3 dapat dilihat rata-rata hasil pretest kelas eksperimen adalah sebesar 39,19 dengan standar simpangan baku 9,17, skor terendah 20 dan skor tertinggi 60, skor yang terbanyak diraih adalah 12 sebanyak 9 peserta didik. Simpangan baku mempunyai nilai yang besar sehingga semakin besar pula perbedaan perolehan nilai satu sama lain, dengan kata lain nilai yang dicapai semakin heterogen. Terdapat kesenjangan nilai terendah dan nilai tertinggi terhadap nilai rata-rata. 


\section{Histogram}

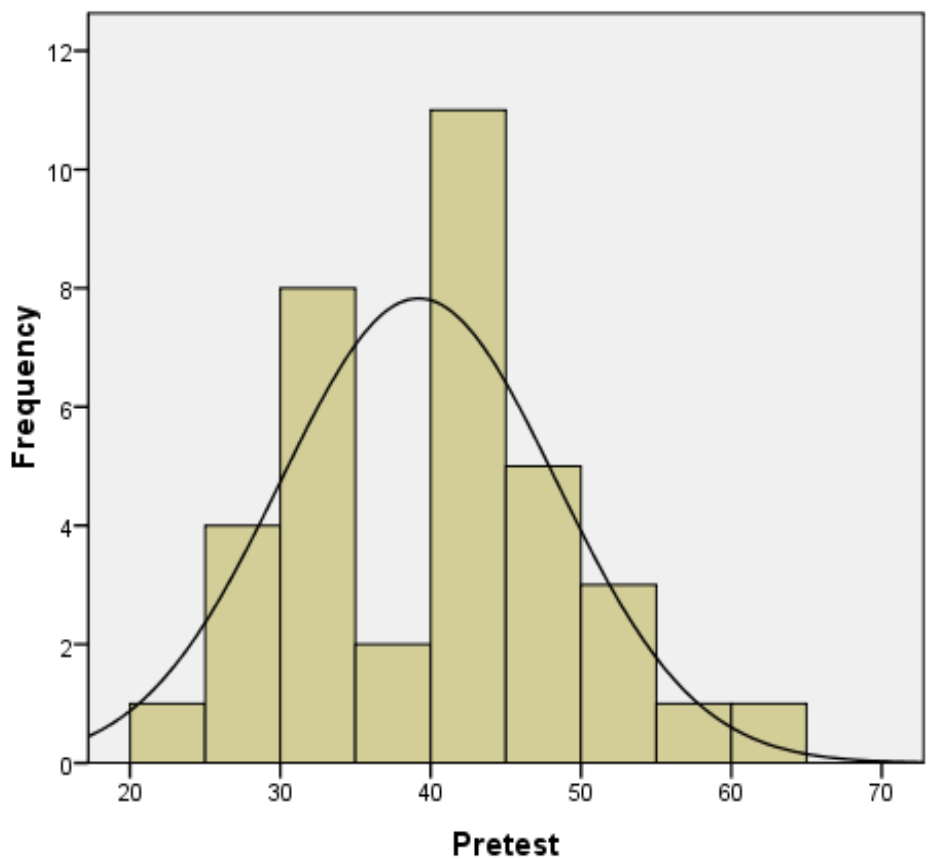

$$
\begin{aligned}
& \text { Mean }=39.19 \\
& \text { Std. Dev }=9.174
\end{aligned}
$$

Sumber : Hasil perhitungan data, 2013

\section{Gambar 4.1}

Grafik Rata-rata Hasil Pretest Kelas Eksperimen

\section{2) Hasil Posttest Kelas Eksperimen}

Posttest diberikan pada kelas eksperimen sesudah pembelajaran dengan metode inkuiri dilaksanakan. Jumlah butir soal adalah 30, yang terdiri dari 25 butir soal berbentuk pilihan ganda dan 5 butir soal berbentuk uraian. Data tersebut disajikan pada tabel 4.4 di halaman berikutnya. 
Tabel 4.4

Data Posttest Kelas Eksperimen

\begin{tabular}{|l|r|}
\hline \multicolumn{1}{|c|}{ Vostidest } & 36 \\
Mean & 0 \\
Std. Error of Mean & 70.44 \\
Median & 1.650 \\
Mode & 71.50 \\
Std. Deviation & 73 \\
Variance & 9.901 \\
Skewness & 98.025 \\
Std. Error of Skewness & -.539 \\
Kurtosis & .393 \\
Std. Error of Kurtosis & .674 \\
Range & .768 \\
Minimum & 47 \\
Maximum & 43 \\
\hline
\end{tabular}

Sumber: Hasil pengolahan data, 2013

Dari tabel 4.4 dapat dilihat bahwa rata-rata hasil posttest kelas eksperimen adalah sebesar 70,44 dengan simpangan baku 9,90, skor terendah 43 dan skor tertinggi adalah 90, skor yang terbanyak diraih adalah 22 sebanyak 6 peserta didik. Perbandingan nilai terendah dan nilai tertinggi, rata-rata nilai yang diraih oleh peserta didik pada kelas eksperimen mendekati nilai rata-rata, simpangan baku mempunyai nilai yang besar, sehingga nilai perolehan yang diraih peserta didik mempunyai perbedaan. 


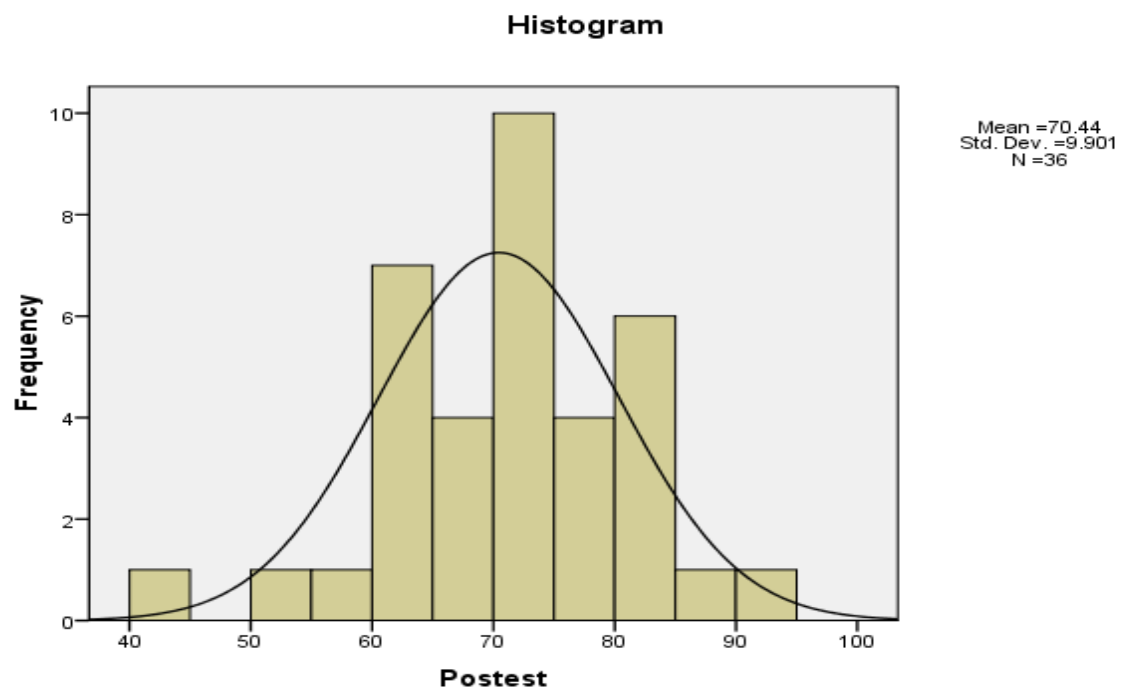

Gambar 4.2

Grafik Rata-rata Hasil Posttest Kelas Eksperimen

Dari data-data pretest dan posttest diperoleh gambaran perubahan skor pada kelas eksperimen adalah sebagai berikut :

Tabel 4.5

Gain Skor Hasil Belajar Peserta Didik Kelas Eksperimen

Skor kelas eksperimen

\begin{tabular}{|c|c|c|c|}
\hline N & Rata-rata Pretest & Rata-rata Posttest & Gain \\
\hline 36 & 11,31 & 21,14 & 0,53 \\
\hline
\end{tabular}

Sumber: Hasil pengolahan data, 2013

Dari tabel 4.5 dapat dilihat bahwa gain skor hasil belajar peserta didik di kelas eksperimen adalah sebesar 0,53, maka kelas eksperimen dapat dikategorikan kepada kriteria sedang, dan ini berarti terjadi perubahan skor pada kelas eksperimen, walaupun perubahannya sedang akan tetapi ada peningkatan yang signifikan.

\subsection{Deskripsi Kelas Kontrol}

1) Hasil Pretest Kelas Kontrol

Pretest kemampuan berpikir kritis siswa diberikan dalam bentuk 25 butir soal pilihan ganda dan 5 butir soal uraian. Data pretest kelas kontrol ditampilkan pada tabel 4.6 berikut ini 
Tabel 4.6

Data Pretest Kelas Kontrol

Pretest
\begin{tabular}{|l|r|}
\hline \multicolumn{1}{|c|}{ Valid } & 36 \\
Mean & 0 \\
Std. Error of Mean & 42.53 \\
Median & 2.189 \\
Std. Deviation & 40.00 \\
Variance & 13.136 \\
Skewness & 172.542 \\
Std. Error of Skewness & -.144 \\
Kurtosis & .393 \\
Std. Error of Kurtosis & -1.382 \\
Range & .768 \\
Minimum & 40 \\
Maximum & 23 \\
\hline
\end{tabular}

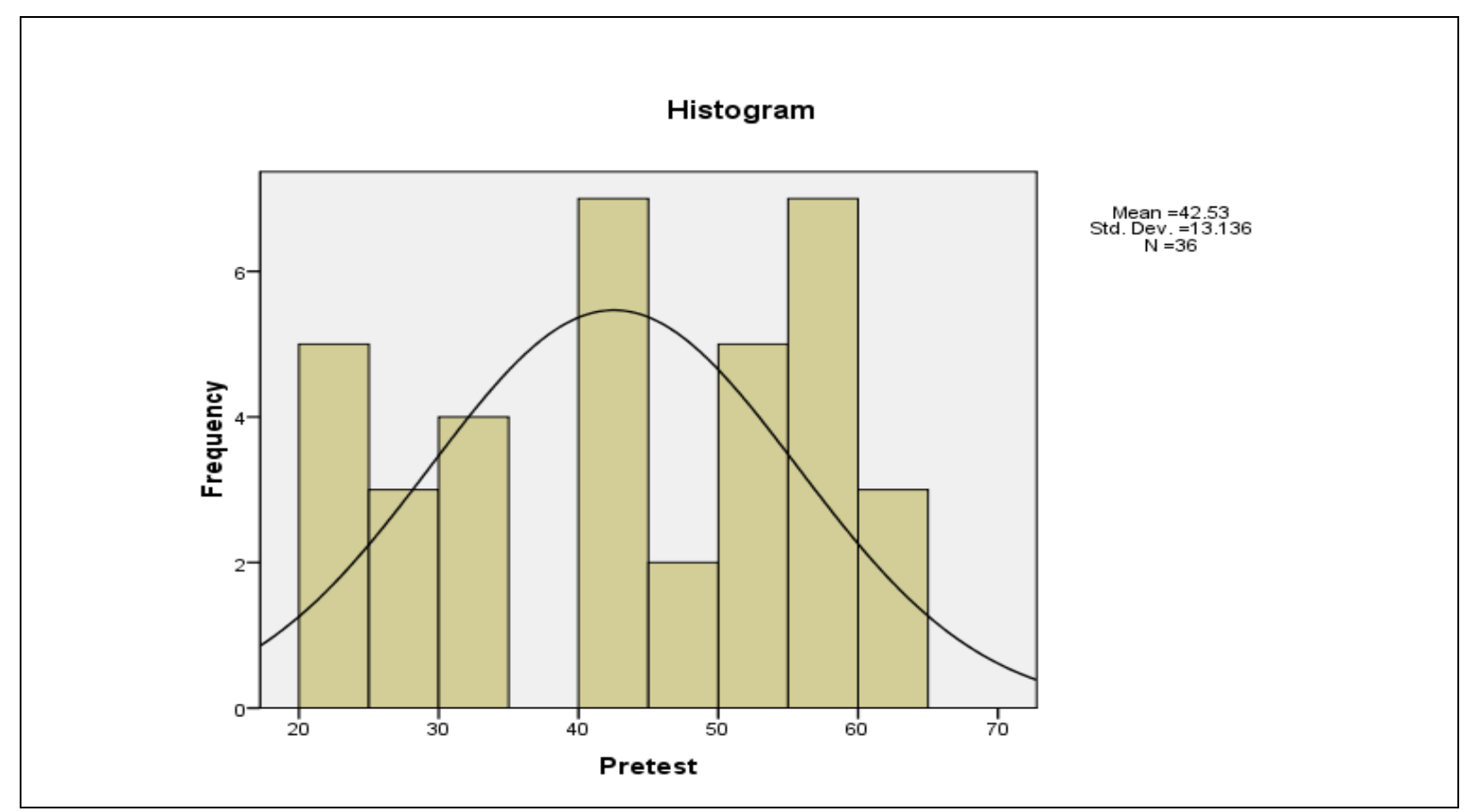

Sumber : Hasil perhitungan data, 2013

Gambar 4.3

Grafik Rata-rata Hasil Pretest Kelas Kontrol

Dari data tabel dan grafik dapat dilihat bahwa rata-rata hasil pretest kelas kontrol adalah sebesar 42,53 dengan simpangan baku sebesar 13,13, skor terendah adalah 23 dan skor tertinggi adalah 63. 


\section{2) Hasil Posttest Kelas Kontrol}

Untuk hasil posttest berpikir kritis siswa diberikan dalam bentuk 25 butir soal pilihan ganda dan 5 butir soal uraian. Dapat dilihat pada tabel 4.7 di halaman berikutnya.

Tabel 4.7

Data Posttest Kelas Kontrol

Posttest

\begin{tabular}{|l|r|}
\hline \multicolumn{1}{|c|}{ Valid } & 36 \\
Mean & 0 \\
Std. Error of Mean & 53.08 \\
Median & 2.258 \\
Std. Deviation & 55.00 \\
Variance & 13.549 \\
Skewness & 183.564 \\
Std. Error of Skewness & -.206 \\
Kurtosis & .393 \\
Std. Error of Kurtosis & -1.324 \\
Range & .768 \\
Minimum & 43 \\
Maximum & 30 \\
\hline
\end{tabular}

Histogram

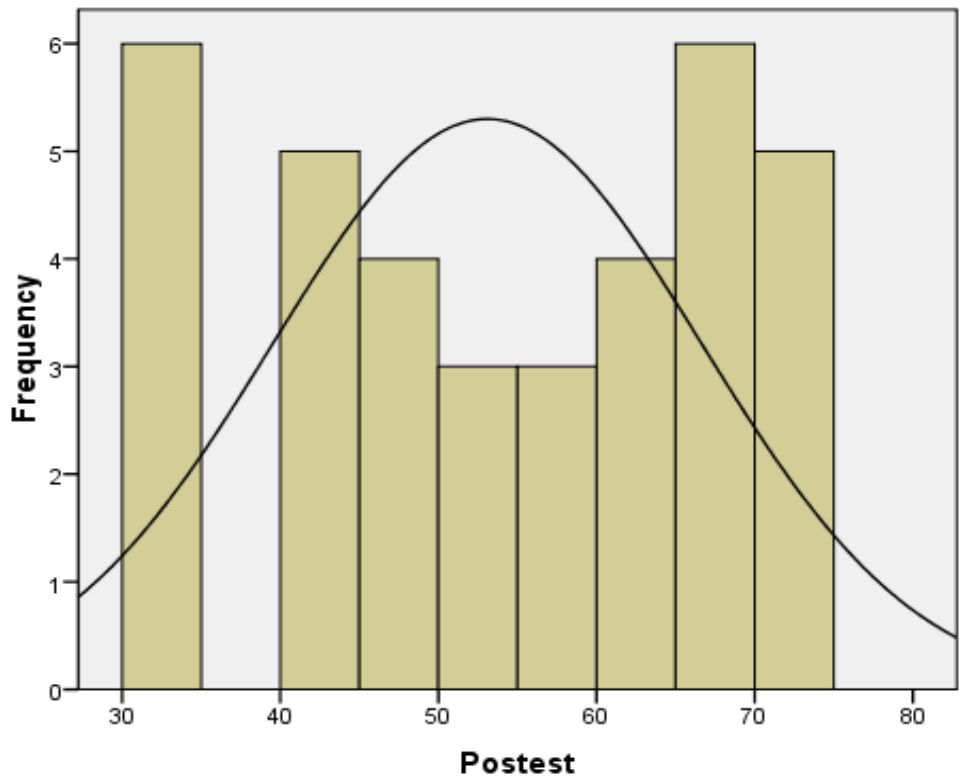
Mean $=53.08$
Std. Dev. $=13.549$
$N=36$

Gambar 4.4

Grafik Rata-rata Hasil Posttest Kelas Kontrol 
Dari tabel dan grafik dapat dilihat bahwa rata-rata hasil posttest kelas kontrol sebesar 53.08 dengan simpangan baku sebesar 13,55, skor terendah 30 dan skor tertinggi adalah 73 .

Dari data-data hasil pretest dan posttest diperoleh gambaran perubahan skor pada kelas kontrol sebagai berikut :

Tabel 4.8

Gain Skor Hasil Belajar Peserta Didik Kelas Kontrol

\begin{tabular}{|c|c|c|c|}
\hline \multicolumn{4}{|c|}{ Skor kelas kontrol } \\
\hline $\mathrm{N}$ & Rata-rata Pretest & Rata-rata Posttest & Gain \\
\hline 36 & 12,75 & 15,97 & 0,19 \\
\hline
\end{tabular}

Sumber: Hasil pengolahan data, 2013

Dari tabel 4.8 dapat dilihat bahwa gain skor hasil belajar peserta didik di kelas kontrol adalah sebesar 0,19. Ini menunjukkan bahwa hasil belajar peserta didik pada kelas kontrol masih rendah.

\subsection{Proses Pembelajaran}

\section{1) Kelas Eksperimen}

Pelaksanaan pembelajaran merupakan implementasi dari RPP yang meliputi kegiatan pendahuluan, kegiatan inti dan kegiatan penutup. Proses pembelajaran dalam penelitian ini dilaksanakan sebanyak 3 kali pertemuan dan terbagi menjadi 2 bagian yaitu yang pertama di luar kelas dengan memanfaatkan lingkungan sekitar (kawasan Punclut ) sebagai sumber pembelajaran dan pertemuan kedua dan ketiga di dalam kelas dengan menggunakan metode inkuiri untuk pencapaian berpikir kritis.

\section{Pembelajaran di luar kelas}

Untuk pelaksanaan di luar kelas terdapat 3 fase yaitu :

\section{Fase I Persiapan}

a. Sebelum masuk kedalam proses pembelajaran dengan menggunakan lingkungan sekitar sekolah, dalam hal ini kawasan Punclut sebagai sumber belajar, guru menjelaskan mengenai Standar kompetensi dan kompetensi dasar yang akan dicapai pada pembelajaran sesuai dengan materi yaitu siklus hidrologi.

b. Guru menjelaskan tentang prosedur pada saat menggunakan kawasan Punclut sebagai sumber belajar dengan mempersiapkan format pengamatan atau data observasi. Data observasi lapangan berisi 4 kriteria yang mendukung Kawasan Punclut sebagai daerah tangkapan air hujan/cacthment area yaitu :

1. Vegetasi (banyaknya vegetasi dan jenis vegetasi yang tumbuh di kawasan Punclut akan mempengaruhi resapan air hujan (infiltrasi), yang merupakan salah satu bagian dari siklus hidrologi).

2. Pola penggunaan lahan (dilihat secara umum penggunaan lahan di sekitar kawasan Punclut, dipergunakan untuk kebun, tegalan, pemukiman atau dibiarkan begitu saja sehingga ada kaitannya dengan resapan air hujan ).

3. Kemiringan lereng (dilihat secara visual, kemiringan lereng antara $15^{\circ}-45^{\circ}$, semakin miring lereng semakin cepat aliran air hujan yang jatuh apalagi bila di atas lereng dipenuhi dengan pemukiman dan tidak bervegetasi), selain itu pengaruh yang ditimbulkan bisa mengakibatkan terjadinya bencana alam yaitu longsor. 
4. Kedalaman air tanah (dalam hal ini tolok ukurnya adalah kedalaman air sumur yang dipergunakan warga sekitar 10 - 20 meter, ini menunjukkan bahwa makin dangkal kedalaman air sumur maka kandungan air tanah biasanya akan tersedia, disamping itu pembuatan sumur resapan di pemukiman penduduk membantu juga untuk memelihara ketersediaan cadangan air tanah).

c. Guru membagi peserta didik ke dalam 6 kelompok yang masing-masing kelompok akan mengamati dan mengumpulkan data/informasi sesuai dengan format data yang telah dipersiapkan.

\section{Fase II Pelaksanaan :}

a. Peserta didik melaksanakan observasi terhadap lingkungan sekitar sekolah (kawasan Punclut) dengan mengacu pada lembar observasi yang telah disediakan guru sesuai dengan materi pembelajaran yaitu siklus hidrologi.

b. Peserta didik melakukan tanya jawab terhadap penduduk sekitar kawasan Punclut kepada ketua RT, ketua RW atau sesepuh masyarakat/pemuka masyarakat untuk melengkapi data observasi.

\section{Fase III Tindak lanjut}

a. Setiap kelompok berdiskusi mengenai tugas yang telah diberikan guna menyusun laporan hasil observasi.

b. Masing-masing kelompok mempresentasikan hasil temuan dan ditanggapi oleh kelompok lain.

Untuk fase tindak lanjut dilakukan pada pertemuan selanjutnya ( di dalam kelas).

Peserta didik yang telah dibagi menjadi 6 kelompok yang masing-masing kelompok disebar ke 6 kampung yang berada di sekitar kawasan Punclut untuk mengamati lingkungan yang berada di sekitar sekolah, berdasarkan pedoman pertanyaan yang telah disiapkan guru. Adapun deskripsi masing-masing kampung yang diamati adalah sebagai berikut :

\section{Kampung Sekejulang Atas}

Di Kampung Sekejulang Atas, tanaman yang tumbuh tidak begitu rapat, dengan jenis tanaman singkong, pisang dan alang-alang. Penggunaan lahan kebanyakan untuk pemukiman dan padat, di Kampung Sekejulang Atas rata-rata mempunyai sumur resapan, sumber air yang dipergunakan penduduk bersumber dari mata air dan sumur gali/artesis, dengan kedalam sumur antara $10 \mathrm{~m}-15 \mathrm{~m}$, berwarna jernih dan dapat dipergunakan untuk air minum, Di tiap rumah yang memiliki halaman kebanyakan ditanami bunga-bungaan. Di sekitar lokasi pengamatan terdapat lereng dengan sudut kemiringan sekitar $15^{\circ}$, di atas lereng terdapat pemukiman yang terdiri dari $1-5$ rumah penduduk. Di kawasan ini belum pernah terjadi longsor/erosi, dan tidak terdapat sungai, pada musim kemarau tidak pernah mengalami kekurangan air dan pada musim hujan tidak pernah banjir. Untuk penghijauan/ reboisasi kawasan ini pernah melakukan reboisasi sebanyak 1 kali dalam satu tahun.

\section{Kampung Rereongan Sarupi}

Tanaman yang tumbuh di kampung ini sangat rapat, di dominasi oleh tanaman tahunan seperti tanaman buah-buahan, mayoritas penggunaan lahan di sekitar lokasi pengamatan dipergunakan untuk pemukiman dan perkebunan, pemukiman penduduk tidak terlalu padat. Sumber air yang dipergunakan berasal dari mata air dan terdapat sumur resapan, kedalaman sumur gali rata-rata $15-20 \mathrm{~m}$, berwarna jernih sehingga bisa dipergunakan untuk minum. Hampir semua rumah di wilayah ini halamannya ditumbuhi dengan sayuran, di sekitar pemukiman terdapat lereng dengan kemiringan lereng kurang dari $45^{\circ}$, dan di atas lereng terdapat pemukiman penduduk sekitar 15 rumah. Pernah mengalami longsor meskipun tidak tiap tahun, jarak pemukiman menuju sungai kurang lebih berjarak $15-20 \mathrm{~m}$, pada musim 
kemarau pernah mengalami kesulitan air dengan frekwensi dua kali dalam setahun, dan tidak pernah banjir. Reboisasi atau penghijauan dilakukan 2 kali dalam setahun.

\section{Kampung Cipicung Hilir}

Kampung Cipicung Hilir dipenuhi oleh tanaman sayuran dan tanaman tahunan, dipadati aneka jenis tanaman dan sangat rapat. Kebanyakan penggunaan lahan diperuntukkan untuk perkebunan sayuran, buah-buahan dan singkong, sedangkan pemukiman sangat jarang. Di pemukiman penduduk terdapat sumur resapan, air yang dipergunakan penduduk untuk kebutuhan sehari-hari berasal dari mata air, dan tidak terdapat sumur gali. Di setiap rumah yang memiliki halaman ditanami aneka jenis tanaman, di sekitar lokasi terdapat lereng dengan kemiringan kurang lebih $25^{\circ}$ dan diatasnya terdapat rumah tinggal lebih 15 rumah. Belum pernah mengalami longsor/erosi, jarak kampung dengan sungai kira-kira $5-10 \mathrm{~m}$, pada musim kemarau penduduk pernah mengalami kesulitan air setahun dua kali, belum pernah terjadi banjir. Usaha penghijauan /reboisasi dilakukan dua kali dalam setahun.

\section{Kampung Cihanja}

Tanaman yang tumbuh di Kampung Cihanja sangat rapat, dengan jenis tanaman mayoritas sayuran. Penggunaan lahan adalah untuk perkebunan dan pemukiman yang padat. Di pemukiman penduduk terdapat sumur resapan, air yang dipergunakan penduduk bersumber dari mata air, terdapat beberapa sumur gali dengan kedalaman antara $15-20 \mathrm{~m}$, air sumur berwarna jernih dan bisa dipergunakan sebagai air minum. Halaman rumah penduduk banyak ditanami bunga-bungaan, dan di sekitar pemukiman terdapat lereng dengan ketinggian $25^{0}$ di atasnya ada sekitar $1-5$ rumah penduduk. Pernah mengalami longsor satu kali dalam setahun, terdapat sungai yang berjarak 15-20 m dari pemukiman penduduk. Pada musim kemarau di kampung tersebut pernah mengalami kesulitan air satu kali dalam setahun, dan tidak pernah mengalami banjir. Penghijauan atau reboisasi pernah dilaksanakan di Kampung Cihanja sebanyak dua kali dalam satu tahun.

\section{Kampung Sekejulang Bawah}

Di Kampung Sekejulang Bawah tanaman tumbuh sangat rapat, dengan jenis tanaman sayuran. Selain untuk pemukiman penggunaan lahan di kampung ini diperuntukkan untuk perkebunan, dan terdapat sumur resapan. Air yang dipergunakan penduduk berasal dari sumur gali/artesis dengan kedalaman $25 \mathrm{~m}$ lebih, warna air jernih dan dapat dipergunakan untuk minum. Di halaman rumah tiap penduduk ditanami tanaman kebanyakkan berupa sayursayuran. Di sekitar lokasi terdapat lereng dengan kemiringan lereng sekitar $15^{\circ}$ dan diatasnya terdapat rumah tinggal sekitar 11 - 15 rumah. Belum pernah mengalami longsor/erosi dan tidak terdapat sungai. Pada waktu musim kemarau penduduk di sekitar kampung ini belum pernah mengalami kekeringan atau kesulitan air, dan tidak pernah terjadi banjir. Penghijauan atau reboisasi rutin dilakukan dengan frekwensi tiga kali dalam satu tahun.

\section{Kampung Sekejulang}

Tanaman yang tumbuh di kampung ini intensitas sedang, dengan jenis tanaman singkong dan sayuran. Penggunaan lahan dimanfaatkan untuk pemukiman dan perkebunan. Pemukiman tidak begitu rapat dan terdapat sumur resapan. Untuk kebutuhan sehari-hari penduduk menggunakan air dari mata air dan sumur gali/artesis, warna air sumur jernih dan dapat dipakai sebagai air minum. Di halaman rumah penduduk ditanami dengan bungabungaan. Kemiringan lereng di sekitar lokasi kira-kira $15^{0}$ dan di atasnya terdapat pemukiman penduduk lebih dari 15 rumah. Di Kampung Sekejulang belum pernah mengalami longsor atau erosi, dan tidak terdapat sungai. Pada musim kemarau penduduk mengalami kesulitan air satu kali dalam satu tahun, dan tidak pernah mengalami banjir. Usaha penghijauan atau reboisasi dilakukan dua kali dalam setahun. Untuk lebih jelasnya, dapat dilihat pada tabel 4.9 di halaman berikutnya. 


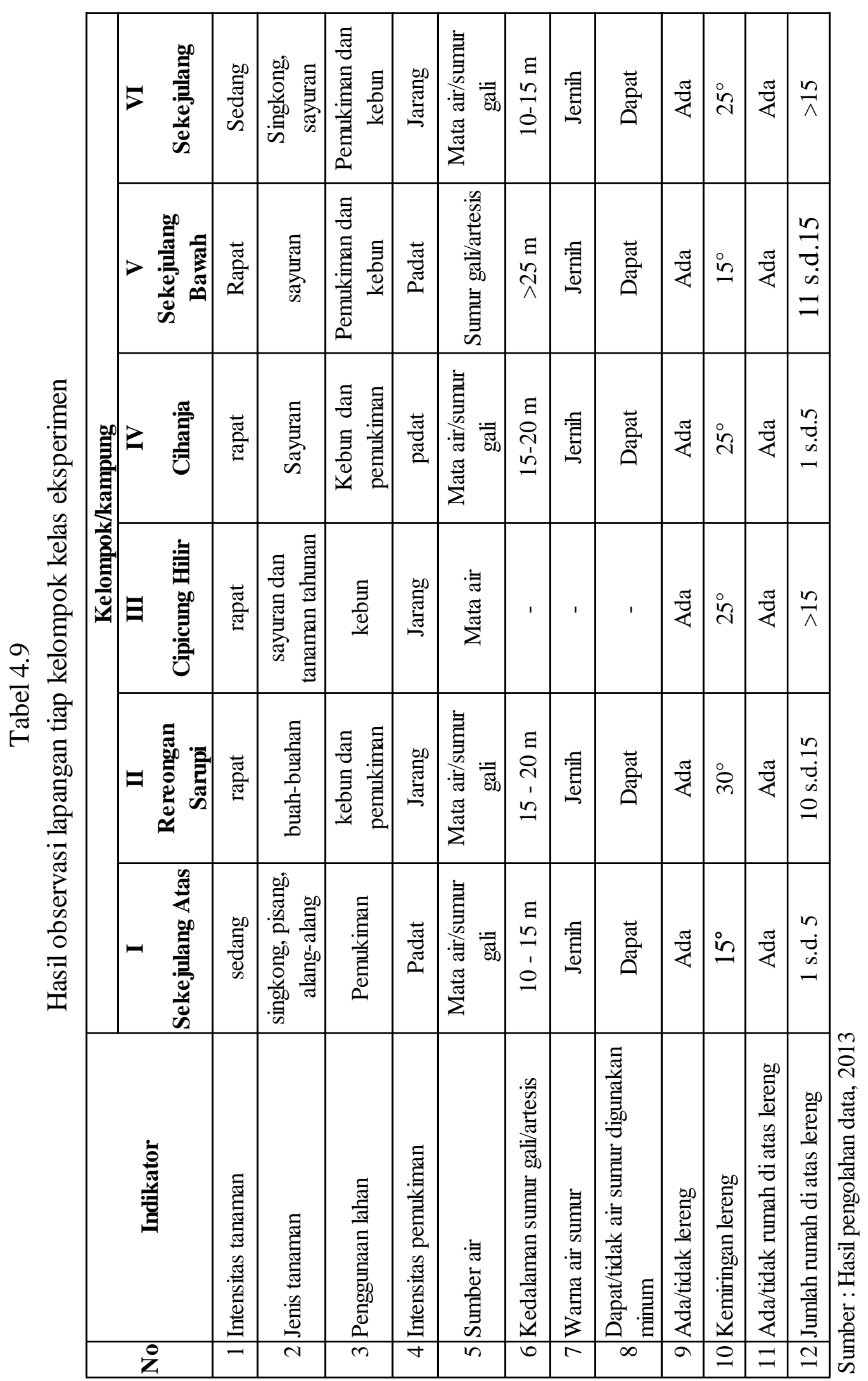




\section{Pembelajaran di dalam kelas}

Untuk pelaksanaan pembelajaran di dalam kelas terdapat 4 kegiatan sebagai berikut :

\section{1) Kegiatan Pendahuluan}

Menyiapkan peseta didik, menjelaskan tujuan pembelajaran atau kompetensi dasar yang akan dicapai, mengajukan pertanyaan-pertanyaan yang mengaitkan pengetahuan sebelumnya dengan materi yang akan dipelajari.

\section{2) Kegiatan inti}

Peserta didik mencoba untuk merumuskan masalah yang ada di lapangan dengan berpedoman pada data lapangan yang telah diobservasi pada pertemuan sebelumnya, kemudian peserta didik yang sudah terbagi ke dalam kelompok-kelompok diskusi yang terdiri dari 5-6 peserta didik, kemudian melakukan diskusi dan mengidentifikasi terhadap fakta-fakta yang ditemukan di lapangan yang terkait dengan permasalahan yang akan dikaji untuk dijadikan bahan diskusi kelompok.

Guru berkeliling dan sesekali masuk ke dalam kelompok secara bergiliran untuk memotivasi peserta didik menentukan pendapat dan mengemukakan alasan dari pendapat tersebut. Setelah itu masing-masing dari perwakilan kelompok mempresentasikan hasil-hasil diskusi di depan kelas, kemudian peserta didik mengkaji ulang proses/hasil pemecahan masalah dan terakhir mengidentifikasi terhadap asumsi-asumsi faktual disini peran guru membimbing siswa untuk menidentifikasi dan menguji secara faktual.

\section{3) Kegiatan Penutup}

Guru berserta peserta didik membuat kesimpulan, melakukan pretest atau refleksi terhadap kegiatan yang sudah dilaksanakan, memberikan umpan balik terhadap proses pembelajaran dan hasil pembelajaran, merencanakan kegiatan tindak lanjut serta menyampaikan rencana pembelajaran pada pertemuan berikutnya.

\section{4) Penilaian Pembelajaran}

Penilaian dilakukan oleh guru terhadap hasil pembelajaran untuk mengukur tingkat pencapaian kompetensi peserta didik dalam hal ini cara berpikir kritis peserta didik, serta digunakan sebagai penyusunan laporan kemajuan hasil belajar, dan memperbaiki proses pembelajaran. Pada penelitian ini penilaian dilakukan dengan penjumlahan skor yang meliputi skor aktifitas kelompok (menggunakan format observasi berpikir kritis dan hasil observasi lapangan) serta skor tes tulis untuk pemahaman konsep.

Untuk lebih jelasnya akan diuraikan sebagai berikut : proses pembelajaran di dalam kelas, diawali guru dengan membuka dan menyampaikan SK dan KD yang akan dipelajari, selanjutnya guru mengingatkan kembali observasi lapangan yang telah dilaksanakan, untuk memperkuat materi guru menayangkan film animasi mengenai siklus hidrologi. Tahap selanjutnya guru mengorientasi siswa pada permasalahan yang ditemukan di lapangan yang berkaitan dengan siklus hidrologi. Dari masingmasing kelompok yang diwakili ketua kelompok melaporkan hasil observasi di lapangan, hasil temuan tiap kelompok mengenai kasus-kasus atau permasalahan yang terjadi di sekitar lingkungan sekolah. Dengan memperhatikan kasus tersebut peserta didik diharapkan dapat menyusun, memecahkan serta mengembangkan permasalahan yang berkaitan dengan siklus hidrologi.

Tahap selanjutnya kelompok yang sudah terbagi menjadi 6 kelompok dengan jumlah anggota 5-6 orang mendapat satu permasalahan yang harus mereka diskusikan dan dianalisis. Selama proses diskusi berlangsung, guru memperhatikan secara seksama dan mengevaluasi kerja masing-masing kelompok. Setelah menyelesaikan tugasnya, wakil dari masing-masing kelompok memaparkan hasil kerjanya di depan kelas. Pada tahap evaluasi, bersama-sama dengan siswa, guru mengkaji ulang proses hasil pemecahan masalah dan memberikan penjelasan mengenai hal-hal yang menjadi permasalahan dalam diskusi kelompok.

Pada akhir pembelajaran guru menunjuk seorang peserta didik untuk menyampaikan pemahamannya terhadap konsep dalam pembelajaran yang telah dilaksanakan, untuk selanjutnya guru menunjuk seorang peserta didik untuk menyampaikan kesan terhadap pembelajaran yang telah 
dilaksanakan. Sebagai bahan masukan untuk pertemuan selanjutnya guru menginformasikan materi pelajaran yang akan disampaikan nanti.

Pada pertemuan ke dua di dalam kelas proses pembelajaran berlangsung lebih baik dari pertemuan sebelumnya, Langkah-langkah dalam pembelajaran dilaksanakan seperti dalam pertemuan-pertemuan sebelumnya. Peserta didik tampak lebih aktif dalam kegiatan diskusi, dan tampak mulai menguasai materi, dalam kerja kelompok tiap peserta didik terlibat dalam menyelesaikan masalah, sudah berani menyampaikan pendapat dengan landasan teori yang baik sehingga suasana kelas menjadi aktif. Tugas guru sebagai fasilitator sudah tampak. Dari observasi yang dilakukan pada tiap kelompok menunjukkan bahwa hampir semua indikator berpikir kritis peserta didik mengalami peningkatan, ini menunjukkan adanya pengaruh pembelajaran pemanfaatan lingkungan sekitar melalui metode inkuiri terhadap berpikir kritis peserta didik.

Dari hasil kegiatan pembelajaran di kelas eksperimen pada pertemuan pertama di dalam kelas, masing-masing kelompok belum terlihat adanya perubahan berpikir kritis, pada masing-masing indikator berpikir kritis kebanyakan hanya mendapat nilai 1-2 point dari jumlah keseluruhan 25 point. Hal ini dapat dilihat dari tabel 4.10 di halaman berikutnya.

Tabel 4.10 Hasil Observasi Kelas Eksperimen Pertemuan 1

\begin{tabular}{|c|c|c|c|c|c|c|c|c|}
\hline \multirow[b]{2}{*}{ No } & \multirow[b]{2}{*}{ Indikator berpikir kritis } & \multicolumn{6}{|c|}{ Perolehan Nilai Tiap Kelompok } & \multirow[b]{2}{*}{ Jml } \\
\hline & & $\begin{array}{c}\text { Kel } \\
1 \\
\end{array}$ & $\begin{array}{c}\text { Kel } \\
2 \\
\end{array}$ & $\begin{array}{c}\text { Kel } \\
3 \\
\end{array}$ & $\begin{array}{c}\text { Kel } \\
4 \\
\end{array}$ & $\begin{array}{c}\text { Kel } \\
5 \\
\end{array}$ & $\begin{array}{c}\text { Kel } \\
6 \\
\end{array}$ & \\
\hline 1 & Orientasi pada masalah & 1 & 2 & 1 & 2 & 1 & 1 & 8 \\
\hline 2 & $\begin{array}{l}\text { Mengorganisasikan belajar } \\
\text { untuk meneliti }\end{array}$ & 1 & 1 & 1 & 1 & 1 & 1 & 6 \\
\hline 3 & Memecahkan masalah & 2 & 2 & 1 & 2 & 1 & 1 & 9 \\
\hline 4 & $\begin{array}{l}\text { Mengembangkan dan } \\
\text { menyajikan hasil } \\
\text { pemecahan masalah }\end{array}$ & 1 & 2 & 1 & 1 & 1 & 1 & 7 \\
\hline 5 & $\begin{array}{l}\text { Menganalisis dan } \\
\text { mengevaluasi proses } \\
\text { pemecahan masalah }\end{array}$ & 2 & 1 & 2 & 1 & 1 & 1 & 8 \\
\hline & Perolehan skor & 7 & 8 & 6 & 7 & 5 & 5 & 38 \\
\hline & Total skor & 25 & 25 & 25 & 25 & 25 & 25 & 150 \\
\hline & Persentase & $28 \%$ & $32 \%$ & $24 \%$ & $28 \%$ & $20 \%$ & $20 \%$ & \\
\hline
\end{tabular}

Sumber : Hasil pengolahan data, 2013

Pada pertemuan ke dua di dalam kelas, mulai terlihat ada perubahan cara berpikir kritis pada peserta didik, ini ditunjukkan dengan perolehan nilai dari masing-masing indikator berpikir kritis pada rentang 1- 5 point.

Pada Tabel 4.11 dapat dilihat adanya perubahan yang signifikan dari pertemuan sebelumnya dalam aktivitas berpikir kritis peserta didik di kelas eksperimen, Pada indikator memecahkan masalah mendapatkan jumlah skor yang paling tinggi yakni sebesar 17, berarti pada metode inkuiri siswa sangat antusias dalam memecahkan masalah yang diberikan, karena masalah-masalah yang diberikan adalah masalah yang berkaitan dengan pemanfaatan lingkungan di sekitar peserta didik sehingga mereka sangat termotivasi untuk belajar memecahkan masalah yang ada di lingkungan sekitarnya. 
Tabel 4.11 Hasil Observasi Kelas Eksperimen Pertemuan 2

\begin{tabular}{|c|c|c|c|c|c|c|c|c|}
\hline \multirow{2}{*}{ No } & \multirow{2}{*}{$\begin{array}{c}\text { Indikator berpikir } \\
\text { kritis }\end{array}$} & \multicolumn{6}{|c|}{ Perolehan Nilai Tiap Kelompok } & \multirow[b]{2}{*}{ Jml } \\
\hline & & $\begin{array}{c}\mathrm{Kel} \\
1\end{array}$ & $\begin{array}{c}\text { Kel } \\
2\end{array}$ & $\begin{array}{c}\text { Kel } \\
3\end{array}$ & $\begin{array}{c}\text { Kel } \\
4\end{array}$ & Kel & $\begin{array}{c}\mathrm{Kel} \\
6\end{array}$ & \\
\hline 1 & Orientasi pada masalah & 2 & 3 & 3 & 3 & 2 & 2 & 15 \\
\hline 2 & $\begin{array}{l}\text { Mengorganisasikan } \\
\text { belajar untuk meneliti }\end{array}$ & 1 & 2 & 2 & 2 & 1 & 1 & 9 \\
\hline 3 & Memecahkan masalah & 3 & 4 & 4 & 3 & 1 & 2 & 17 \\
\hline 4 & $\begin{array}{l}\text { Mengembangkan dan } \\
\text { menyajikan hasil } \\
\text { pemecahan masalah }\end{array}$ & 1 & 2 & 2 & 2 & 2 & 1 & 10 \\
\hline \multirow[t]{4}{*}{5} & $\begin{array}{l}\text { Menganalisis dan } \\
\text { mengevaluasi proses } \\
\text { pemecahan masalah }\end{array}$ & 2 & 3 & 4 & 3 & 2 & 2 & 16 \\
\hline & Perolehan skor & 10 & 14 & 15 & 13 & 8 & 8 & 67 \\
\hline & Total skor & 25 & 25 & 25 & 25 & 25 & 25 & 150 \\
\hline & Presentase & $40 \%$ & $56 \%$ & $60 \%$ & $52 \%$ & $32 \%$ & $32 \%$ & \\
\hline
\end{tabular}

Sumber : Hasil pengolahan data, 2013

Pada indikator menganalisis dan mengevaluasi proses pemecahan masalah mendapat skor 16, ini menunjukkan bahwa peserta didik terpacu untuk mencari dan mencoba menganalisa dan mengevaluasi permasalahan-permasalahan yang terjadi kemudian mencarikan bagaimana solusi dari permasalahan yang ada di lingkungannya, sehingga dampak yang ditimbulkan dapat dicegah atau diminimalisir.

Pada indikator orientasi pada masalah meraih point 15 , terlihat ada upaya peserta didik untuk lebih memilih dan menimbang permasalahan yang berkaitan dengan lingkungan, awalnya peserta didik merasa kebingungan dengan pemilihan masalah, pada pertemuan sebelumnya mendapat skor 8 berubah menjadi 15 . Skor yang baik juga diperoleh dari indikator mengembangkan dan menyajikan hasil pemecahan masalah yakni sebesar 10, peserta didik dituntut untuk mencari tambahan data dan referensi untuk melengkapi dan menyajikan hasil pemecahan masalah agar lebih akurat, karena biasanya guru yang memberi informasi kepada peserta didik atau hanya dari membaca buku paket saja. Skor terendah yaitu 9 pada indikator mengorganisasikan belajar untuk meneliti, disini terlihat peserta didik kesulitan karena belum terbiasa dengan model pembelajaran dari metode inkuiri, untuk mengangkat masalah yang ada di lingkungannya, karena biasanya gurulah yang menginformasikan segala sesuatu kepada siswa (teacher centered), melalui metode inkuiri cara berpikir kritis peserta didik mengalami perubahan karena peserta didik dibiasakan mengikuti langkah-langkah dalam berpikir kritis.

\section{2) Kelas Kontrol}

Pembelajaran di kelas kontrol dilaksanakan dengan metode konvensional atau ceramah yang diselingi tanya jawab dan diskusi. Pada awal pembelajaran guru membuka dengan informasi mengenai materi dan tujuan pembelajaran, dengan mengajukan beberapa pertanyaan pembuka. Kegiatan inti dari pembelajaran adalah guru menyampaikan materi dan peserta didik mencatat apa yang disampaikan oleh guru, kadang guru bertanya atau memberi penugasan untuk membaca atau melakukan diskusi.

Pada pertemuan pertama guru membuka dan menyampaikan SK dan KD, kemudian guru menerangkan materi dan memperlihatkan gambar mengenai siklus hidrologi . Setelah materi selesai diberikan, guru mempersilahkan peserta didik untuk bertanya tentang materi yang sudah disampaikan yang ada kaitannya dengan lingkungan di sekolah. Dari hasil pengamatan hanya sebagian kecil 
peserta didik yang bertanya, ada beberapa peserta didik yang acuh tak acuh atau hanya diam. Pada akhir pertemuan guru menyimpulkan materi yang telah diberikan dan menugaskan kepada peserta didik untuk mencari referensi yang ada kaitannya dengan materi selanjutnya.

Pertemuan kedua pada kelas kontrol dimulai seperti pada pertemuan pertama, guru memberi motivasi kepada siswa dan sebagai apersepsi guru memberi pertanyaan yang berhubungan dengan materi yang telah disampaikan pada pertemuan sebelumnya. Pada kegiatan inti guru membagi peserta didik ke dalam 6 kelompok untuk melakukan diskusi dan mengerjakan tugas kelompok dengan tema yaitu tentang permasalahan lingkungan di sekitar sekolah (kawasan Punclut) yang ada kaitannya dengan siklus hirologi yang telah diberikan pada pertemuan sebelumnya. Setelah selesai berdiskusi, masing-masing kelompok mempresentasikan hasilnya dan dilanjutkan dengan tanya jawab. Beberapa peserta didik tampak pasif dalam berdiskusi, dan pada tanya jawab, sebagian peserta didik menjawab dengan asal dan kadang tidak dilandasi dengan teori, data, dan referensi lain yang berkaitan dengan materi. Dari hasil observasi pada pertemuan ke dua, dari 5 indikator berpikir kritis masing-masing kelompok hanya meraih nilai 1 dan 2 dari skala rentang nilai 1 sampai 5 . Seperti pada tabel 4.12 berikut ini.

Tabel 4.12 Hasil Observasi kelas kontrol

\begin{tabular}{|c|c|c|c|c|c|c|c|c|}
\hline \multirow[b]{2}{*}{ No } & \multirow[b]{2}{*}{ Indikator berpikir kritis } & \multicolumn{6}{|c|}{ Perolehan Nilai Tiap Kelompok } & \multirow[b]{2}{*}{ Jml } \\
\hline & & $\begin{array}{c}\text { Kel } \\
1\end{array}$ & $\begin{array}{c}\text { Kel } \\
2\end{array}$ & $\begin{array}{c}\text { Kel } \\
3\end{array}$ & Kel & $\frac{\mathrm{Kel}}{5}$ & $\begin{array}{c}\text { Kel } \\
6\end{array}$ & \\
\hline 1 & Orientasi pada masalah & 1 & 1 & 1 & 1 & 2 & 1 & 7 \\
\hline 2 & $\begin{array}{l}\text { Mengorganisasikan belajar } \\
\text { untuk meneliti }\end{array}$ & 1 & 1 & 1 & 1 & 1 & 1 & 6 \\
\hline 3 & Memecahkan masalah & 1 & 2 & 1 & 2 & 1 & 2 & 9 \\
\hline 4 & $\begin{array}{l}\text { Mengembangkan dan } \\
\text { menyajikan hasil pemecahan } \\
\text { masalah }\end{array}$ & 1 & 2 & 1 & 1 & 1 & 1 & 7 \\
\hline 5 & $\begin{array}{l}\text { Menganalisis dan } \\
\text { mengevaluasi proses } \\
\text { pemecahan masalah } \\
\end{array}$ & 1 & 1 & 2 & 1 & 2 & 1 & 8 \\
\hline & Perolehan skor & 5 & 7 & 6 & 6 & 7 & 6 & 37 \\
\hline & Total skor & 25 & 25 & 25 & 25 & 25 & 25 & 150 \\
\hline & Presentase & $20 \%$ & $28 \%$ & $24 \%$ & $24 \%$ & $28 \%$ & $24 \%$ & \\
\hline
\end{tabular}

Sumber : Hasil pengolahan data, 2013

Dari tabel 4.12 dapat dilihat jumlah nilai yang diraih oleh peserta didik di kelas kontrol tidak jauh berbeda dengan peserta didik di kelas eksperimen pada pertemuan pertama di dalam kelas.

Pada pembelajaran di kelas eksperimen pada pertemuan pertama di dalam kelas meraih skor 38, sedangkan pada pembelajaran di kelas kontrol meraih skor 37, hal ini menunjukkan pada pertemuan kedua pada kelas kontrol belum tampak adanya pengaruh pembelajaran berpikir kritis peserta didik, meskipun dibandingkan dengan pertemuan pertama, pertemuan kedua dalam pembelajaran di kelas kontrol dengan melaksanakan diskusi kelompok mengalami peningkatan dibandingkan dengan pertemuan yang pertama atau sebelumnya.

\section{B. Uji Prasyarat Analisis}

Uji prasyarat analisis dilakukan sebelum uji hipotesis, yang meliputi uji normalitas dan homogenitas data. Data diolah dengan bantuan program SPSS 16. 


\section{1) Uji Normalitas Kelas Eksperimen}

Uji normalitas dilakukan untuk mengetahui apakah suatu variabel normal atau tidak. Tujuannya adalah untuk mengetahui apakah data yang diambil adalah data yang terdistribusi normal. Data terdistribusi normal maksudnya adalah data akan mengikuti bentuk distribusi normal dimana datanya memusat pada nilai rata.rata. Dalam penelitian ini, uji normalitas yang dilakukan adalah dengan menggunakan uji Kolmogorov-Smirnov. Hasil uji normalitas kelas eksperimen dapat dilihat pada tabel di bawah ini :

Tabel 4.13

Tests of Normality Kelas Eksperimen

\begin{tabular}{|c|c|c|c|c|c|c|}
\hline & \multicolumn{3}{|c|}{ Kolmogorov-Smirnov $^{\mathrm{a}}$} & \multicolumn{3}{c|}{ Shapiro-Wilk } \\
\cline { 2 - 7 } & Statistic & $\mathrm{df}$ & Sig. & Statistic & df & Sig. \\
\hline Pretest & .118 & 36 & $.200^{*}$ & .976 & 36 & .598 \\
Postest & .102 & 36 & $.200^{*}$ & .971 & 36 & .458 \\
\hline
\end{tabular}

Sumber : Hasil pengolahan data, 2013

Dari hasil uji normalitas pada tabel di atas, dengan melihat nilai Kolmogorof Smirnov diketahui nilai Sig. Kolmogorof Smirnov sebesar 0,200 untuk kelas eksperimen baik itu pretest maupun postest yang menunjukkan lebih besar dari $0,05(0,200>0,05)$ sehingga dapat disimpulkan bahwa data terdistribusi dengan normal.

\section{2) Tes Homogenitas Kelas Eksperimen}

Uji homogenitas dimaksudkan untuk memperlihatkan dua atau lebih kelompok data sampel berasal dari populasi yang memiliki variansi yang sama. Pengujian homogenitas varian bertujuan untuk mengetahui setara atau tidaknya kelas eksperimen dengan kelas kontrol. Untuk menentukan homogen atau tidaknya suatu data adalah dengan melihat tingkat signifikasinya, jika tingkat signifikansinya lebih besar dari 0,05 maka data dinyatakan homogen, demikian pula sebaliknya.

Dengan kata lain, uji homogenitas ini bertujuan untuk membandingkan lebih dari dua ratarata dan berguna untuk menguji kemampuan generalisasi artinya data sampel dianggap dapat mewakili populasi.

Kriteria pengujian yang dilakukan yaitu menggunakan nilai Sig. apabila nilai Sig kurang atau sama dengan $\alpha$ yang ditetapkan (5\%) dari hasil Test of Homogeneity of Variances, maka data tidak homogen, apabila nilai Sig lebih besar atau sama dengan $\alpha$ maka data tersebut homogen. Berikut ini penyajian mengenai uji homogenitas data hasil penelitian.

Tabel 4.14

Test of Homogeneity of Variances Kelas Eksperimen

Pretest

\begin{tabular}{|c|c|c|c|}
\hline Levene Statistic & df1 & df2 & Sig. \\
\hline 1.500 & 6 & 23 & .222 \\
\hline
\end{tabular}

Sumber: Hasil pengolahan data, 2013

Asumsi dalam pengujian Anova bahwa varian kelompok data adalah sama atau homogen. Kriteria pengujiannya, yaitu jika signifikansi <0,005, maka varian kelompok data tidak sama, sebaliknya, jika signifikansi >0,005, maka varian kelompok data adalah sama. Dari uji hommogenitas kelas eksperimen diatas, terlihat bahwa tingkat signifikansinya adalah lebih besar dari 0,005 yaitu 
0,222 > 0,005, dengan demikian dapat disimpulkan bahwa data bersifat homogen karena menunjukan varian kelompok data yang sama.

\section{3) Uji Normalitas Data Kelas Kontrol}

Uji normalitas dilakukan dengan menggunakan SPSS versi 16 dengan kriteria $\geq 0,05$ terdistribusi normal. Dalam penelitian ini, uji normalitas yang dilakukan adalah dengan menggunakan uji Kolmogorov-Smirnov. Hasil uji normalitas kelas kontrol dapat dilihat pada tabel di bawah ini :

Tabel 4.15

Tests of Normality Kelas Kontrol

\begin{tabular}{|l|c|c|c|c|c|c|}
\hline \multirow{2}{*}{} & \multicolumn{3}{|c|}{ Kolmogorov-Smirnov $^{\mathrm{a}}$} & \multicolumn{3}{c|}{ Shapiro-Wilk } \\
\cline { 2 - 7 } & Statistic & Df & Sig. & Statistic & Df & Sig. \\
\hline Pretest & .142 & 36 & .062 & .909 & 36 & .006 \\
Postest & .153 & 36 & .032 & .918 & 36 & .011 \\
\hline
\end{tabular}

Sumber :Hasil Pengolahan data, 2013

Dari hasil uji normalitas pada tabel di atas, dengan melihat nilai Kolmogorof Smirnov diketahui nilai Sig. Kolmogorof Smirnov sebesar 0,062 untuk kelas kontrol menunjukkan lebih besar dari $0,05(0,062>0,05)$ sehingga dapat disimpulkan bahwa data terdistribusi dengan normal.

\section{4) Uji Homogenitas Kelas Kontrol}

Kriteria pengujian yang dilakukan dalam uji homogenitas yaitu menggunakan nilai Sig. apabila nilai Sig kurang atau sama dengan $\alpha$ yang ditetapkan (5\%) dari hasil Test of Homogeneity of Variances, maka data tidak homogen, apabila nilai Sig lebih besar atau sama dengan $\alpha$ maka data tersebut homogen. Berikut ini penyajian mengenai uji homogenitas data hasil penelitian.

Tabel 4.16

Test of Homogeneity of Variances Kelas Kontrol

Pretest

\begin{tabular}{|c|c|c|c|}
\hline Levene Statistic & df1 & df2 & Sig. \\
\hline 3.407 & 8 & 23 & .010 \\
\hline
\end{tabular}

Kriteria pengujiannya, yaitu jika signifikansi $<0,005$, maka varian kelompok data tidak sama, sebaliknya, jika signifikansi >0,005, maka varian kelompok data adalah sama. Dari uji hommogenitas diatas total skor pre test terlihat bahwa tingkat signifikansinya adalah lebih besar dari 0,005 yaitu $0,010>0,005$, menunjukan varian kelompok data adalah sama.

\section{Uji Hipotesis}

\section{1) Hasil Pretest dan Posttest Peserta Didik Kelas Eksperimen}

Pada kelas eksperimen, hasil pretest dan posttest peserta didik pada dianalisis untuk melihat perbedaan yang signifikan antara hasil pretest dan posttest setelah diberikan perlakuan. Adapun perbandingan data pretest dan posttest kelas eksperimen dapat dilihat pada tabel 4.17 di bawah ini : 
Tabel 4.17

Hasil Pretest dan Posttest Kemampuan Berpikir Kritis Peserta Didik Kelas Eksperimen Paired Samples Statistics

\begin{tabular}{|ll|c|c|c|c|}
\hline & & Mean & N & Std. Deviation & Std. Error Mean \\
\hline Pair 1 & Pretest & 39.19 & 36 & 9.174 & 1.529 \\
& Postest & 70.44 & 36 & 9.901 & 1.650 \\
\hline
\end{tabular}

Paired Samples Test

\begin{tabular}{|c|c|c|c|c|c|c|c|c|}
\hline & \multicolumn{5}{|c|}{ Paired Differences } & & \multirow{3}{*}{$d f$} & \multirow{3}{*}{$\begin{array}{l}\text { Sig. (2- } \\
\text { tailed) }\end{array}$} \\
\hline & \multirow[t]{2}{*}{ Mean } & \multirow{2}{*}{$\begin{array}{c}\text { Std. } \\
\text { Deviation }\end{array}$} & \multirow{2}{*}{$\begin{array}{l}\text { Std. Error } \\
\text { Mean }\end{array}$} & \multicolumn{2}{|c|}{$\begin{array}{l}95 \% \text { Confidence } \\
\text { Interval of the } \\
\text { Difference }\end{array}$} & & & \\
\hline & & & & Lower & Upper & & & \\
\hline Pair 1 Pretest - Postest & -31.250 & 6.809 & 1.135 & -33.554 & -28.946 & -27.537 & 35 & .000 \\
\hline
\end{tabular}

Sumber : Hasil perhitungan data, 2013

Dari hasil penghitungan pretest dan posttest pada kelas eksperimen dengan menggunakan metode statistik Paired Samples T Test diatas, untuk data pretest dengan bentuk soal pilihan ganda nilai rata - rata test 39,19 dengan jumlah data 36, standar deviasi 9,174 dan standar error mean 1,529. Sedangkan untuk data posttest dengan bentuk soal pilihan ganda, nilai rata - rata test 70,44, jumlah data 36 dengan standar deviasi 9,901 dan standard error mean 1,650. Sedangkan pada Paired Samples $T$ Test digunakan untuk mengetahui apakah ada perubahan antara pretest dan posttest dengan menggunakan tingkat signifikan 0,05 dengan merumuskan hipotesis sebagai berikut :

Ho : Tidak ada perbedaan antara nilai rata - rata nilai pre test dan post test.

Ha : Ada perbedaan antara nilai rata - rata nilai pre test dan post test.

Dari penghitungan statistik diatas maka diketahui bahwa $-\mathrm{t}$ hitung $<-\mathrm{t}$ tabel $-27,537<-1,690$ dan tingkat signifikansi $<0,05(0,000<0,005)$, maka Ho ditolak. Jadi dapat disimpulkan bahwa ada perbedaan antara rata - rata nilai antara pretest dan posttest pada siswa yang memanfaatkan lingkungan sekitar (kawasan Punclut) sebagai sumber belajar melalui metode inkuiri.

Hasil posttest siswa yang memanfaatkan lingkungan sekitar (kawasan Punclut) sebagai sumber belajar melalui metode inkuiri lebih baik dari hasil pretest. Dengan demikian ada perbedaan hasil belajar siswa antara hasil pretest dan posttest pada siswa yang memanfaatkan lingkungan sekitar (kawasan Punclut) sebagai sumber belajar melalui metode inkuiri.

\section{2) Hasil pretest dan posttest peserta didik kelas kontrol}

Hasil pretest dan posttest yang diperoleh peserta didik pada kelas kontrol dianalisis untuk melihat apakah ada perbedaan yang signifikan antara hasil pretest dan posttest jika tanpa diberi perlakuan. Perbandingan data pretest dan posttest pada kelas kontrol dapat dilihat pada tabel 4.18 :

Tabel 4.18

Hasil Pretest dan Posttest Kemampuan Berpikir Kritis Peserta Didik Kelas Kontrol

Paired Samples Statistics

\begin{tabular}{|c|c|c|c|c|c|}
\hline & & Mean & $\mathrm{N}$ & Std. Deviation & Std. Error Mean \\
\hline \multirow[t]{2}{*}{ Pair 1} & Pretest & 42.53 & 36 & 13.136 & 2.189 \\
\hline & Postest & 53.08 & 36 & 13.549 & 2.258 \\
\hline
\end{tabular}




\section{- $\quad$ Paired Samples Test}

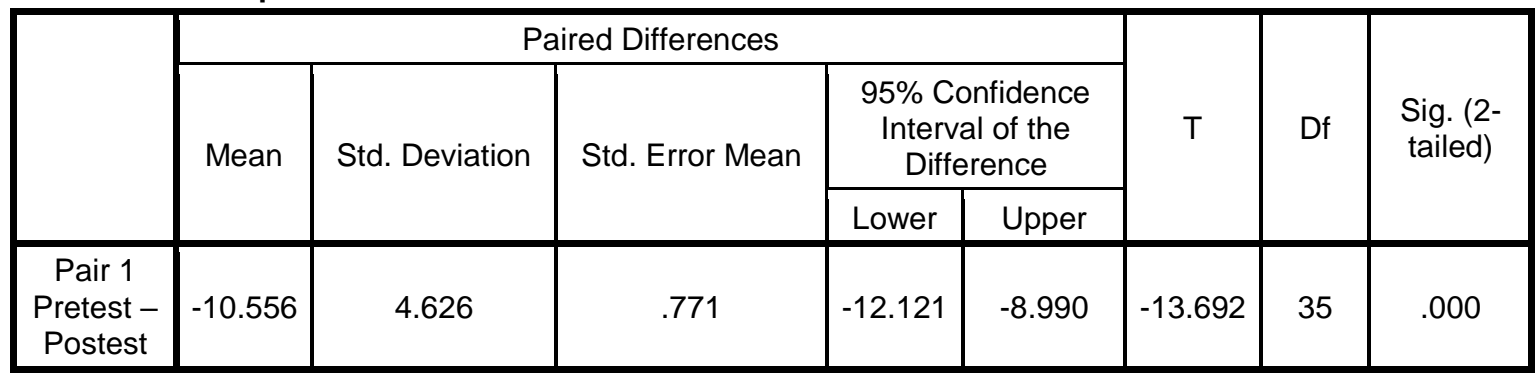

Sumber : hasil perhitungan data, 2013

Dari hasil penghitungan statistik hasil pretest dan posttest pada kelas kontrol dengan menggunakan metode statistik Paired Samples T Test diatas, untuk data pretest dengan bentuk soal pilihan ganda nilai rata - rata test 42,53 dengan jumlah data 36, standar deviasi 13,136 dan standar error mean 2,189. Sedangkan untuk data posttest dengan bentuk soal pilihan ganda, nilai rata - rata test 53,08, jumlah data 36 dengan standar deviasi 13,549 dan standard error mean 2,258. Sedangkan pada Paired Samples $T$ Test digunakan untuk mengetahui apakah ada perubahan antara pretest dan posttest pada kelas control dengan menggunakan tingkat signifikan 0,05 dengan merumuskan hipotesis sebagai berikut :

Ho : Tidak ada perbedaan antara nilai rata - rata nilai pretest dan posttest.

Ha : Ada perbedaan antara nilai rata - rata nilai pretest dan posttest.

Dari penghitungan statistik diatas maka diketahui bahwa $-t$ hitung $<-t$ tabel $-13,692<-1,690$ dan tingkat signifikansi $<0,05(0,000<0,005)$, maka Ho ditolak. Jadi dapat disimpulkan bahwa ada perbedaan antara rata - rata nilai antara pretest dan posttest pada siswa kelas kontrol yang mendapatkan pembelajaran dengan metode konvensional/ceramah.

Hasil posttest siswa yang mendapatkan pembelajaran dengan metode konvensional lebih baik dari hasil pretest. Dengan demikian ada perbedaan hasil belajar siswa antara hasil pretest dan posttest pada siswa yang mendapatkan pembelajaran dengan metode konvensional/ceramah.

\section{3) Hasil Pretest-Posttest Antara Kelas Eksperimen dan Kelas Kontrol}

Dalam penelitian ini dianalisis perbedaan gain skor pretest dan posttest antara kelas eksperimen dan kelas kontrol.

Adapun uji statistik parametrik dengan hipotesis pretest yang diajukan adalah :

$\mathrm{Ha}$ : Hipotesis yang berbunyi ada perbedaan hasil belajar antara siswa yang memanfaatkan lingkungan sekitar (kawasan Punclut) sebagai sumber belajar melalui metode inkuiri dan siswa yang mendapatkan pembelajaran konvensional pada pengukuran awal (pretest).

Ho : Hipotesis nihil berbunyi tidak ada perbedaan hasil belajar antara siswa yang memanfaatkan lingkungan sekitar (kawasan Punclut) sebagai sumber belajar melalui metode inkuiri dan siswa yang mendapatkan pembelajaran konvensional pada pengukuran awal (pretest).

Kriteria pengujian berdasarkan :

- Jika nilai sig $<0,05=$ maka $\mathrm{h}_{0}$ ditolak

- Jika nilai sig $>0,05=$ maka $h_{0}$ diterima

Deskripsi gain skor pretest di kelas eksperimen dan kelas kontrol dapat dilihat pada tabel 4.19 di bawah ini : 
Tabel 4.19

Deskripsi Perubahan Skor Pretest Pada Kelas Eksperimen dan Kelas Kontrol

Paired Samples Statistics

\begin{tabular}{|c|c|c|c|c|c|}
\hline & & Mean & $\mathrm{N}$ & Std. Deviation & Std. Error Mean \\
\hline \multirow[t]{2}{*}{ Pair 1} & Kel. Eksperimen & 39.1944 & 36 & 9.17394 & 1.52899 \\
\hline & Kel. Kontrol & 42.5278 & 36 & 13.13553 & 2.18925 \\
\hline
\end{tabular}

Sumber : Hasil Perhitungan data, 2013

Pada tabel 4.19 dapat dilihat bahwa rata-rata gain pretest pada kelas eksperimen adalah 9,17394 dan rata-rata gain pretest pada kelas kontrol adalah 13,13553, hal ini berarti tidak ada perbedaan yang berarti antara kelas eksperimen dan kelas kontrol, yang menarik disini adalah hasil belajar pada kelas kontrol pada pretest ternyata lebih tinggi dibandingkan pada kelas eksperimen. Untuk membuktikan bahwa terdapat perbedaan gain pretest pada pemanfaatan lingkungan pada kelas eksperimen dan kelas kontrol dilakukan uji t dengan hasil yang tertera pada tabel 4.20 berikut ini :

Tabel 4.20

Uji-t Perubahan Skor Hasil Belajar Pretest Kelas Eksperimen dan Kelas Kontrol

Paired Samples Test

\begin{tabular}{|c|c|c|c|c|c|c|c|c|}
\hline & \multicolumn{5}{|c|}{ Paired Differences } & \multirow[b]{3}{*}{$\mathrm{T}$} & \multirow[b]{3}{*}{$\mathrm{df}$} & \multirow{3}{*}{$\begin{array}{l}\text { Sig. (2- } \\
\text { tailed) }\end{array}$} \\
\hline & \multirow[b]{2}{*}{ Mean } & \multirow{2}{*}{$\begin{array}{c}\text { Std. } \\
\text { Deviation }\end{array}$} & \multirow{2}{*}{$\begin{array}{l}\text { Std. Error } \\
\text { Mean }\end{array}$} & \multicolumn{2}{|c|}{$\begin{array}{l}95 \% \text { Confidence Interval } \\
\text { of the Difference }\end{array}$} & & & \\
\hline & & & & Lower & Upper & & & \\
\hline $\begin{array}{cl}\text { Pair } 1 & \text { Kel. Eksperimen } \\
& \text { - Kel. Kontrol }\end{array}$ & -3.33333 & 15.87811 & 2.64635 & -8.70571 & 2.03905 & -1.260 & 35 & .216 \\
\hline
\end{tabular}

Sumber : Hasil Pengolahan data, 2013

Berdasarkan analisis data tersebut, Ha ditolak dan Ho diterima. Jadi dapat disimpulkan tidak ada perbedaan hasil belajar antara siswa yang memanfaatkan lingkungan sekitar (kawasan Punclut) sebagai sumber belajar melalui metode inkuiri dan siswa yang mendapatkan pembelajaran konvensional pada pengukuran awal (pretest).

Dengan demikian hasil pretest atau pengukuran awal sebelum diberikan perlakuan tidak ada perbedaan hasil belajar antara siswa yang memanfaatkan lingkungan sekitar (kawasan Punclut) sebagai sumber belajar melalui metode inkuiri dan siswa yang mendapatkan pembelajaran konvensional. Sedangkan uji parametrik statistik dengan hipotesis posttest yang diajukan adalah:

$\mathrm{Ha}$ : Hipotesis kerja yang berbunyi ada perbedaan hasil belajar antara siswa yang memanfaatkan lingkungan sekitar (kawasan Punclut) sebagai sumber belajar melalui metode inkuiri dan siswa yang mendapatkan pembelajaran konvensional pada pengukuran akhir (posttest).

Ho : Hipotesis nihil berbunyi tidak ada perbedaan hasil belajar antara siswa yang memanfaatkan lingkungan sekitar (kawasan Punclut) sebagai sumber belajar melalui metode inkuiri dan siswa yang mendapatkan pembelajaran konvensional pada pengukuran akhir (posttest).

Kriteria pengujian :

- Jika nila sig $<0,05=$ maka $\mathrm{h}_{0}$ ditolak

- Jika nilai sig $>0,05=$ maka $_{0}$ diterima 
Deskripsi gain skor posttest di kelas eksperimen dan kelas kontrol dapat dilihat pada tabel 4.21 berikut :

Tabel 4.21

Deskripsi Perubahan Skor Posttest Kelas Eksperimen dan Kelas Kontrol Group Statistics

\begin{tabular}{|ll|r|r|r|r|}
\hline & Perlakuan & N & Mean & \multicolumn{1}{c|}{ Std. Deviation } & \multicolumn{1}{c|}{$\begin{array}{c}\text { Mtd. Error } \\
\text { Mean }\end{array}$} \\
\hline Nilai Posttest & Inkuiri Lingkungan Sekitar & 36 & 70.4444 & 9.90078 & 1.65013 \\
& Pembelajaran Konvensional & 36 & 53.0833 & 13.54859 & 2.25810 \\
\hline
\end{tabular}

Sumber : Hasil Pengolahan data, 2013

Pada tabel 4.21 dapat dilihat rata-rata gain posttest pada kelas eksperimen adalah 70,4444 dan rata-rata gain posttest pada kelas kontrol adalah 53,0833, ini membuktikan bahwa pada kelas eksperimen yang menggunakan metode inikuiri dan memanfaatkan lingkungan sekitar terjadi perubahan yang positif sebesar 70,4444, sementara pada kelas kontrol yang menggunakan pembelajaran konvensional terjadi pula perubahan yang positif akan tetapi tidak sebesar pada kelas eksperimen yakni hanya sebesar 53,0833.

Untuk membuktikan bahwa terdapat perbedaan gain pada kelas eksperimen dan kelas kontrol dilakukan uji t dengan hasil seperti yang terdapat dalam tabel 4.22 berikut ini :

Tabel 4.22

Uji-t Perubahan Skor Hasil Belajar Posttest Kelas Eksperimen dan Kelas Kontrol

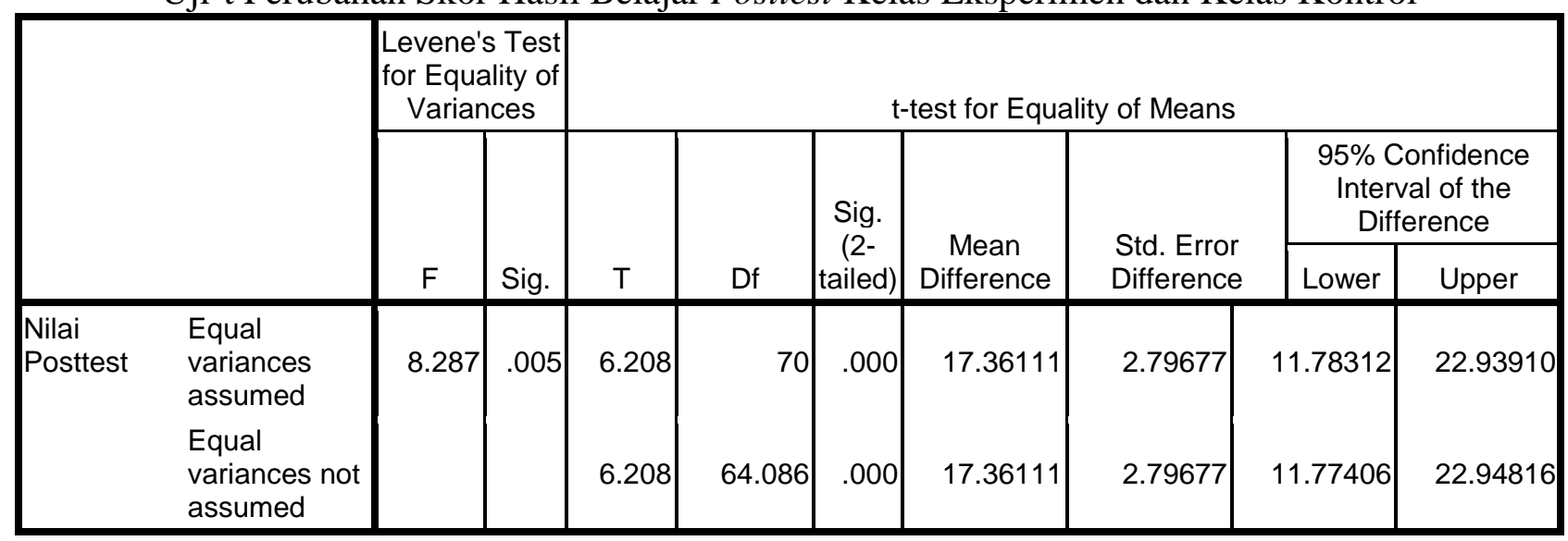

Sumber : Hasil Perhitungan data, 2013

Dari tabel 4.22 dapat dilihat bahwa pada bagian equal variances assumed t-hitung $=6,208$ dan probabilitas sig $(2$ tailed $)=0,00$. Karena probabilitas $<0,05$ maka berdasarkan analisis data tersebut, Ho ditolak dan Ha diterima. Jadi dapat disimpulkan ada perbedaan hasil belajar siswa antara siswa yang memanfaatkan lingkungan sekitar (kawasan Punclut) sebagai sumber belajar melalui metode inkuiri dan siswa yang mendapatkan pembelajaran konvensional pada pengukuran akhir (posttest).

Hasil posttest siswa yang mendapatkan pembelajaran dengan metode inkuiri dengan memanfaatkan lingkungan sekitar lebih baik dari siswa yang mendapatkan pembelajaran konvensional. Dengan demikian ada perbedaan hasil belajar antara siswa yang memanfaatkan lingkungan sekitar (kawasan Punclut) sebagai sumber belajar melalui metode inkuiri dan siswa yang mendapatkan pembelajaran konvensional pada pengukuran akhir (posttest).

Hasil wawancara dengan peserta didik yang bernama Jajang Sanjaya kelas 7-1, mengenai pemanfaatan lingkungan sekitar sebagai sumber belajar adalah sebagai berikut : 
"Bagus kalau guru mengajak muridnya belajar keluar kelas, karena murid sudah bosan belajar di dalam kelas, jika belajar di luar kelas murid akan mendapat pengalaman yang baru apalagi mengenai kawasan Punclut. Dengan memanfaatkan lingkungan sekitar sebagai sumber belajar dapat meningkatkan cara berpikir kritis untuk menyelesaikan masalah yang ada di sekeliling kita, dan kita dapat melihat langsung masalah-masalah yang ada dekat tempat kita tinggal ".

Begitu juga dengan hasil wawancara dengan peserta didik yang bernama Utari Putri Maharani kelas 7-1 sebagai berikut :

" Menurut saya sangat menyenangkan kalau guru mengajak muridnya belajar di luar kelas, karena kita dapat menambah wawasan tentang pemanfaatan lingkungan di kawasan Punclut, karena kita dapat melihat langsung juga supaya kita bisa merawat, memanfatkan dan menjaga kawasan Punclut agar tetap asri. Dengan memanfatkan lingkungan sekitar sebagai sumber belajar dapat meningkatkan cara berpikir kritis supaya bisa mempelajari materi-materi yang terdapat dalam pembelajaran IPS dan dapat membantu mencari solusi bila ada masalah-masalah lingkungan di sekitar Punclut".

Dari kedua pendapat di atas, pemanfaatan lingkungan sekitar merupakan media yang terbaik untuk peserta didik, disamping memberikan motivasi belajar, mengarahkan aktivitas belajar peserta didik, memperkaya pengetahuan dan informasi, meningkatkan hubungan sosial, memperkenalkan lingkungan,juga menumbuhkan sikap dan apresiasi terhadap lingkungan sekitar. Sedangkan hasil belajar yang diharapkan adalah peningkatan kompetensi kognitif, kompetensi keterampilan sosial dan kecintaan terhadap lingkungan sekitar.

Berdasarkan hasil wawancara dengan beberapa guru,kendala yang dihadapi guru dalam memanfaatkan lingkungan sekitar sebagai sumber belajar (kawasan Punclut) dalam meningkatkan cara berpikir kritis peserta didik adalah sebagai berikut :

1. Tebatasnya waktu pelaksanaan.

Guru sering kali kekurangan waktu untuk mengadakan pembelajaran di luar kelas, karena biasanya untuk mengadakan kegiatan pembelajaran di luar kelas cukup memakan waktu meskipun hanya memanfaatkan lingkungan sekitar sekolah.

2. Sosialisasi tentang metode pembelajaran yang tepat.

Guru-guru IPS belum paham dan kurang kemauan untuk mencoba berbagai metode pembelajaran yang tepat karena kekurangtahuan atau keengganan untuk merubah metode pembelajaran yang biasa dipakai.

3. Pemilihan lokasi yang tepat dan harus disesuaikan dengan materi yang akan diajarkan. Guru masih belum mampu mengaitkan materi pembelajaran dengan sumber belajar yang tepat, sehingga masih mengalami kesulitan untuk menentukan lokasi pembelajaran yang tepat yang sesuai dengan pokok bahasan.

4. Pengelolaan peserta didik yang tidak efektif.

Dengan jumlah peserta didik yang banyak diperlukan kepiawaian guru untuk mengorganisir peserta didiknya dan membawanya ke lapangan, diperlukan keberanian yang berlandaskan tanggung jawab untuk mengawasi keselamatan dan ketertiban peserta didik sehingga tujuan pembelajaran dapat tercapai.

5. Kurangnya persiapan peserta didik dari segi keilmuwan, konsep dan daya nalar Peserta didik sebelum mengadakan obseravasi lapangan tidak dibekali dengan ilmu pengetahuan yang cukup dan kurangnya keterampilan sosial peserta didik untuk beradaptasi dengan lingkungan. Sehingga peserta didik mengalami kesulitan di lapangan apa yang mereka harus lakukan.

6. Masalah perizinan dari pihak sekolah.

Perizinan sekolah kadang menjadi kendala, karena pihak sekolah mempunyai aturan yang mengutamakan tingkat keselamatan peserta didik selama berada di lingkungan sekolah.

7. Perencanaan yang kurang matang. 
Dalam melaksanakan suatu kegiatan, kadang guru merencanakan suatu kegiatan kurang terorganisir sehingga hasil yang diharapkan tidak sesuai dengan rencana, dan proses kegiatan belajar mengajar tidak optimal sehingga tujuan pembelajaran tidak tercapai dengan baik.

\section{Pembahasan}

Proses pembelajaran pada penelitian ini terbagi ke dalam 2 bagian yaitu di luar ruangan dengan memanfaatkan Kawasan Punclut dan di dalam kelas dengan menggunakan metode inkuiri untuk meningkatkan cara berpikir kritis peserta didik. Proses pembelajaran terdiri dari perencanaan, pelaksanaan dan penilaian.

Pada tahap perencanaan pembelajaran masih terdapat kesulitan untuk memadukan antara standar kompetensi, kompetensi dasar dan materi ajar mengenai siklus hidrologi dengan pemanfaatan lingkungan sekitar (Kawasan Punclut) dan pemilihan indikator dalam materi ajar harus disesuaikan, pada perencanaan pembelajaran seorang guru membutuhkan kecermatan dan ketelitian sehingga indikator dalam kompetensi dasar dapat relevan dengan lingkungan yang akan diteliti sehingga tujuan pembelajaran dapat tercapai. Pada tahap ini dibutuhkan kepiawaian guru untuk dapat memilih dan memilah permasalahan-permasalahan yang timbul di lingkungan pengamatan dengan pemilihan bahan ajar yang sesuai dan relevan.

Majid (2008: 171) mengemukakan:

Kebermaknaan sumber pembelajaran bagi peserta didik dan guru dapat tercapai apabila diorganisir melalui rancangan dengan memungkinkan seseorang dapat dimanfaatkannya sebagai sumber belajar. Apabila tidak maka tempat atau lingkungan sekitar tidak akan berarti apa-apa.

Sesuai dengan pernyataan di atas, seorang guru harus mampu mengorganisir rancangan pembelajaran dengan baik sehingga lingkungan sekitar dapat dipergunakan dan dimanfaatkan dengan sebaik-baiknya agar tujuan pembelajaran pada peserta didik dapat tercapai.

Dalam proses pelaksanaan pembelajaran dengan memanfaatkan lingkungan sekitar, ketika pertama kali peserta didik diajak ke luar kelas, tampak dari roman muka mereka sangat antusias, sepanjang jalan beberapa peserta didik masih ada yang bercanda dengan temannya, sebagian kecil berjalan tetapi tidak memperhatikan lingkungan yang dilaluinya, sebagian besar peserta didik memperhatikan secara seksama jalan yang mereka lalui dan sangat respek serta memiliki tanggung jawab terhadap kelompoknya, mereka berusaha untuk melengkapi daftar isian pada format observasi lingkungan. Beberapa peserta didik berusaha mewawancarai penduduk sekitar sebagai nara sumber untuk memperkuat data yang akan dimasukkan ke dalam lembar kerja, tampak sebagian peserta didik yang malu-malu untuk bertanya, bahkan ada yang hanya diam memperhatikan teman-temannya.

Secara umum peserta didik sangat senang diajak keluar lingkungan sekolah untuk mengamati permasalahan yang harus mereka pecahkan. Hasil data observasi yang mereka amati bahwa ada relevansi antara ke 4 indikator yaitu mengenai vegetasi yang tumbuh di kawasan Punclut, pola penggunaan lahan, kemiringan lereng dan kedalaman air tanah dalam hal ini dilihat dari kedalaman sumur gali dengan materi pembelajaran mengenai siklus hidrologi. Untuk lebih jelasnya sebagai berikut :

1. Vegetasi

Vegetasi atau tanaman yang tumbuh di kawasan Punclut, secara umum sangat rapat dengan jenis tanaman tahunan, sayuran, dan lain sebagainya. Bila terjadi hujan, air hujan yang masuk ke dalam tanah (infiltrasi) disimpan sebagai air tanah dan sebagian lagi berada di muka bumi sebagai air permukaan sedangkan air hujan yang jatuh di atas vegetasi dapat langsung disimpan di akar-akar tanaman. Semakin banyak vegetasi yang menutupi kawasan Punclut semakin banyak pula air yang disimpan pada akar-akar tanaman. Sehingga ketersediaan air di Kawasan Punclut akan selalu terpelihara dengan baik. 


\section{Pola penggunaan lahan}

Pola penggunaan lahan di Kawasan Punclut secara umum dipergunakan sebagai daerah perkebunan dan pemukiman. Semakin banyak penggunaan lahan untuk perkebunan semakin sedikit resiko akan bahaya erosi muncul, karena tiap tanaman yang menutupi tanah adalah penghambat aliran permukaan. Tanaman yang menutupi permukaan tanah dengan rapat tidak hanya memperlambat aliran air tetapi juga mencegah pengumpulan air secara cepat.

3. Kemiringan lereng

Kemiringan lereng dinyatakan dalam derajat atau persen. Kecuraman lereng $100 \%$ sama dengan kecuraman $45^{\circ}$ (Sitanala Arsyad, 1983:63), makin curam lereng makin besar jumlah aliran permukaan dengan demikian memperbesar kekuatan angkut air. Makin miringnya lereng, maka jumlah butir-butir tanah yang terbawa air hujan akan semakin banyak. Jika lereng permukaan tanah menjadi dua kali lebih curam maka banyaknya erosi menjadi 2-2,5 kali lebih banyak. Lereng-lereng yang berada di Kawasan Punclut sebagian besar bervegetasi sehingga tingkat erosi dapat dihambat dengan vegetasi, walaupun demikian masih ada lereng-lereng yang di atasnya dibangun pemukiman penduduk dan bervegetasi sedikit sehingga menimbulkan bahaya berupa erosi atau longsor.

4. Kedalaman air tanah (sumur gali)

Air tanah adalah air yang berada di dalam lapisan tanah atau tersimpan di pori-pori tanah. Di Kawasan Punclut secara umum sumber air yang dipakai adalah mata air yang berasal dari air tanah yang terletak jauh di bawah permukaan tanah, biasanya dari peresapan air dari daerah tangkapan hujan (cacthment area), sehingga keadaan air tersebut tidak mudah dipengaruhi oleh perubahan musim sehingga volumenya tidak banyak berubah, sumur gali yang dibuat penduduk kedalamannya antara 10 -20 m tidak menjamin ketersediaan air bagi penduduk karena di beberapa kampung di sekitar Kawasan Punclut kadang terjadi kekurangan air di musim kemarau karena sumur gali mereka kering dan tidak berair.

Sedangkan proses pelaksanaan dalam pembelajaran di dalam kelas dengan mempergunakan metode inkuiri yang bertujuan agar peserta didik dilatih untuk mengembangkan serta mempertajam daya pikirnya, sehingga mampu berpikir secara kritis dan melakukan pemecahan masalah yang dihadapi dalam kehidupan sehari-hari. Pada tahap ini guru harus bisa membimbing peserta didik untuk dapat mengungkapkan sebab-sebab persoalan, dampaknya beserta pemecahan permasalahan tersebut. Di dalam kelas terlihat peserta didik masih belum dapat mengidentifikasi masalah, ketika guru bertanya apa permasalahan yang ditemukan di lapangan peserta didik masih belum bisa mengungkapkan secara tepat, begitu pula untuk menjabarkan perkiraan tentang relasi berbagai aspek sosial yang merupakan sebab akibat permasalahan tadi peserta didik masih terdapat kekurangan, penggumpulan atau penggalian informasi yang berkenaan dengan permasalahan belum dilakukan secara optimal, referensi dari buku atau internet juga nara sumber masih sangat terbatas. Penyusunan alternatif pemecahan masalah perlu dibimbing guru secara optimal. Hal ini dikuatkan oleh Nursid Sumaatmadja (1984 : 92) yang mengatakan bahwa melalui teknik dan strategi inkuiri peserta didik pada pengajaran IPS diharapkan mampu :

- Mengidentifikasikan masalah dan pertanyaan tentang hal-hal yang sedang dibahas atau yang sedang dipelajari.

- Membuat referensi dan menarik suatu kesimpulan dari data yang diperoleh.

- Melakukan perbandingan-perbandingan.

- Pengembangan suatu hipotesa atas persoalan yang sedang dibahas atau dipelajari.

- Menggali bukti-bukti untuk menguji hipotesa.

- Merencanakan bagaimana melakukan penelaahan suatu persoaln atau masalah.

- Mengumpulkan data dari berbagai sumber.

- Meramalkan bagaimana perkiraan hasil studi yang bersangkutan.

- Menetukan bukti-bukti yang diperlukan untuk melakukan studi suatu masalah.

- Menentukan informasi-informasi yang relevan dengan masalah yang sedang dibahas. 
Penerapan metode inkuiri di dalam kelas dalam forum diskusi pada pertemuan pertama, tampak sebagian peserta didik masih ragu-ragu dalam menanggapi dan menanyakan permasalahan, tampak pula sebagian dari mereka masih malu-malu dan masih kurang memiliki rasa percaya diri untuk berargumen atau mengeluarkan pendapat, sebagian kecil siswa masih ada yang main-main dan mengobrol dengan teman sebelahnya, ada juga yang kurang berkonsentrasi sehingga tidak memperhatikan kelompok yang sedang mempresentasikan temuannya, sebagian besar siswa sangat antusias bahkan ada yang berani menyanggah pendapat dari temannya akan tetapi alasan yang dikemukakan kurang dikuatkan dengan pembuktian teori yang ada. Masing-masing kelompok masih belum mempunyai keberanian untuk menyampaikan pendapat dan keputusannya, diskusi masih pasif belum hidup secara keseluruhan, diskusi didominasi oleh peserta didik yang pintar. Dalam hal ini metode inkuiri adalah metode yang mengajak peserta didik untuk menemukan masalah, mengidentifikasi masalah, menggambil solusi atau pendapat serta melakukan pengujian terhadap sumsi-asumsi pendapatnya. Posisi guru hanya sedikit membimbing dan mengarahkannya saja. Meskipun belum mencapai hasil yang maksimum proses pembelajaran dapat berlangsung dengan baik, terlihat peserta didik sudah mulai menampakkan sikap ingin tahu dan mulai memahami metode inkuiri.

Selain faktor dari peserta didik, faktor guru juga mempunyai peranan yang sangat penting. Dalam metode inkuiri guru harus mampu memperhitungkan permasalahan pembelajaran yang dihadapi. Beberapa guru masih perlu belajar banyak untuk menghadapi kondisi di lapangan terutama yang berkenaan dengan tingkat jenjang pendidikan, usia peserta didik, jumlah peserta didik, waktu penyampaian serta materi yang menjadi bahan pembahasan. Pada kenyataannya kriteria kemampuan yang diharapkan dari metode inkuiri tidak akan dapat terpenuhi secara tuntas pada satu atau dua kali pertemuan, karena tergantung kepada kondisi di lapangan dan kemampuan guru itu sendiri untuk dapat menerapkan teknik dan strategi tersebut dengan tepat.

Pada proses pembelajaran dalam pertemuan pertama di dalam kelas, belum terlihat aspek berpikir kritis peserta didik, ini dilihat baik dari aspek bertanya dan menjawab masih terlihat asal, kadang tidak berdasarkan teori yang telah diberikan dan tidak berasumsi pada hasil observasi di lapangan. Dari observasi pada tiap kelompok di kelas dari 5 indikator berpikir kritis peserta didik dari rentang skala 1 - 5 masing-masing kelompok peserta didik hanya memperoleh nilai 1 dan 2 .

Pada pertemuan kedua di dalam kelas, mulai terdapat perubahan terlihat peserta didik tampak lebih antusias dan aktif dalam kegiatan berdiskusi, penguasaan materi lebih terlihat dalam kerja kelompok tiap peserta didik terlibat dalam menyelesaikan masalah. Diskusi mulai hidup dan tidak didominasi oleh peserta didik yang pintar, hampir sebagian peserta didik bergiliran untuk bertanya, menjawab atau menanggapi kelompok yang mempresentasikan temuannya. Tugas guru sebagai fasilitator mulai terlihat, guru hanya memfasilitasi dalam diskusi kelompok dengan memperhatikan secara seksama. Pada indikator berpikir kritis peserta didik mengalami peningkatan, pertanyaan, jawaban dan sanggahan serta tanggapan sebagian didasari dengan teori yang telah diberikan ditambah dengan data-data yang telah peserta didik siapkan sebelumnya melalui buku sumber, media informasi dan internet, sehingga pemikiran para peserta didik lebih mengarah pada cara berpikir kritis, menunjukkan bahwa pengaruh pembelajaran dengan memanfaatkan lingkungan sekitar melalui metode inkuiri dapat meningkatkan cara berpikir kritis peserta didik.

Pada tahap penutup dan tahap penilaian tidak mengalami kendala yang berarti, pada tahap penutup, peserta didik memberikan kesimpulan dari hasil pengamatan di lapangan setelah itu guru memperkuat hasil kesimpulan tersebut, sedangkan pada tahap penilaian guru menjumlahkan nilai dari hasil observasi di lapangan, diskusi di dalam kelas, serta kegiatan pretest dan posttest.

Berdasarkan hasil uji hipotesis, dapat dilihat bahwa pada pembelajaran dengan memanfaatkan lingkungan sekitar (kawasan Punclut) melalui metode inkuiri yang dilakukan di kelas eksperimen dapat mendorong peserta didik untuk berpikir kritis. Pembelajaran dimulai dengan mencari permasalahan yang ada di sekitar lingkungan sekolah, yang dapat mendorong rasa ingin tahu peserta didik. Kemampuan berpikir kritis pada kelas eksperimen akan lebih teruji karena pembelajaran 
melalui metode inkuiri merupakan pembelajaran yang aktif yang berpusat pada peserta didik (student centered), dengan mencari permasalahan yang diambil dari pemanfaatan lingkungan sekitar, kemudian peserta didik diminta untuk mencoba mencari pemecahan masalah melalui serangkaian kegiatan berdasarkan teori, konsep dan prinsip yang telah dipelajarinya, peserta didik belajar dari lingkungan sekitar sekolah sehingga peserta didik lebih termotivasi, terlatih untuk menghadapi dan memecahkan masalah yang ada lingkungannya, dipupuk untuk melakukan kerjasama dengan kelompoknya, lebih mandiri dan terbuka pada permasalahan yang ada.

Menurut Sagala (2012:197), ada lima tahapan yang ditempuh dalam melaksanakan pendekatan inkuiri yaikni : (1) perumusan masalah untuk dipecahkan siswa; (2) menetapkan jawaban sementara atau dikenal dengan istilah hipotesis; (3) siswa mencari informasi, data, fakta yang diperlukan untuk menjawab permasalahan/hipotesis; (4) menarik kesimpulan jawaban atau generalisasi dan (5) mengaplikasikan kesimpulan/generalisasi dalam situasi baru. Dari hasil pengamatan pada awalnya peserta didik belum mengerti dengan langkah-langkah yang ada dalam metode inkuiri, karena komunikasi dengan guru biasanya komunikasi satu arah atau komunikasi sebagai aksi, tetapi melalui metode ini komunikasi yang terjadi komunikasi banyak arah atau komunikasi sebagai peran aksi. Tetapi lambat laun peserta didik mulai paham dengan langkahlangkah dalam metode inkuiri sehingga mereka mulai membiasakan diri dan mencoba mengaplikasikannya kepada permasalahan sehingga keterampilan berpikir kritis peserta didik dapat terasah dengan mencoba mencari solusi dari masalah yang mereka hadapi.

Dalam metode inkuiri dapat lebih membiasakan peserta didik untuk membuktikan suatu masalah dengan melakukan penyelidikan yang dibimbing guru, kemudian dianalisis secara bersamasama dengan menggunakan buku-buku referensi dan sumber lain yang berkaitan dengan permasalahan tersebut, pengembangan kognitif dan afektif peserta didik lebih terarah dan dalam kehidupan sehari-hari dapat diaplikasikan secara motorik.

Sedangkan untuk mengukur keterampilan kritis yang terbagi menjadi 5 fase,yaitu fase 1 (orientasi peserta didik pada masalah), fase 2 (mengorganisasikan peserta didik untuk belajar/meneliti, fase 3 (pemecahan masalah), fase 4 (mengembangkan dan menyajikan hasil pemecahan masalah dan fase 5 (menganalisis dan mengevaluasi proses pemecahan masalah.

Menurut data-data hasil penelitian tampak ada perubahan-perubahan yang signifikan sebelum dan sesudah dilaksanakan proses pembelajaran. Nilai rata-rata pretest kelas eksperimen sebesar 39,19, sedangkan nilai posttest sebesar 70,44 . Dengan memanfaatkan lingkungan sekitar melalui metode inkuiri efektif dalam mencapai hasil belajar yang bersifat informasi, fakta dan konsep, tetapi berbeda secara signifikan dalam pencapaian keterampilan berpikir kritis.

Sedangkan pada kelas kontrol proses pembelajaran tidak mempergunakan pemanfaatan lingkungan sekitar sebagai sumber belajar, peserta didik dibantu dengan alat peraga berupa gambargambar mengenai siklus hidrologi dan dampaknya terhadap lingkungan, metode yang dipakai dalam proses pembelajaran yaitu metode ceramah. Daya berpikir kritis peserta didik tidak terasah secara individual karena pada metode ceramah, peran guru sangat dominan, peserta didik tinggal menunggu berbagai macam informasi dari satu sumber yaitu guru, kurangnya kesempatan peserta didik untuk mengembangkan keberanian mengemukakan pendapatnya dan kadang-kadang guru menyajikan ceramah tidak sistematis dan berbelit-belit sehingga menambah kebingungan peserta didik. Penggunaan ceramah baiknya diselingi oleh tanya jawab, ataupun diskusi sehingga peserta didik tidah hanya duduk diam, mendengarkan dan mencatat materi yang disampaikan oleh guru.

Dari hasil uji hipotesis, pretest pada kelas kontrol sebesar 42, 53 sedangkan nilai posttest 53, 08, meskipun ada peningkatan 10,45 dari hasil pretest dan posttest tetapi tidak signifikan. Meskipun tidak signifikan peserta didik di kelas kontrol tetap dapat mengikuti kegiatan pembelajaran dengan baik.

Nilai rata-rata pretest antara kelas eksperimen dengan kelas kontrol memilik perbedaan, karena nilai di kelas kontrol sedikit lebih tinggi dibandingkan di kelas eksperimen. Di kelas kontrol nilai pretest sebesar 42, 53 sedangkan nilai di kelas eksperimen sebesar 39, 19. Meskipun nilai di 
kelas kontrol lebih tinggi dibandingkan dengan di kelas eksperimen akan tetapi tidak ada perbedaan secara signifikan antara kelas eksperimen dan kelas kontrol karena guru belum memberikan perlakuan pada kedua kelas tersebut. Perubahan terjadi setelah dilakukan posttest pada kedua kelas ini, nilai posttest pada kelas eksperimen adalah sebesar 70,44 sedangkan pada kelas kontrol sebesar 53,08 , perbedaan terjadi karena guru telah memberikan perlakuan yang berbeda pada masing-masing kelas. Kelas eksperimen memanfaatkan lingkungan melalui metode inkuiri, sedangkan kelas kontrol diberikan pembelajaran secara konvensional atau melalui ceramah.

Ini menunjukkan bahwa dengan metode pembelajaran inkuiri dengan memanfaatkan lingkungan sekitar (kawasan Punclut) dapat meningkatkan hasil belajar dan berpikir kritis peserta didik, karena peserta didik dilatih untuk mencari permasalahan, mengumpulkan fakta atau data, memecahkan masalah tersebut kemudian mengembangkan dan menganalisis masalah tersebut untuk dicarikan solusinya.

Hasil wawancara dengan peserta didik yang bernama Jajang Sanjaya dan Utari Putri Maharani kelas 7-1, mengenai pemanfaatan lingkungan sekitar sebagai sumber belajar, berlandaskan pada teori yang dikemukakan Sudjana (2011:208) bahwa manfaat dari mempelajari lingkungan sebagai sumber belajar antara lain :

1. Kegiatan belajar akan lebih menarik dan tidak membosankan siswa duduk di kelas berjamjam, sehingga motivasi belajar siswa akan lebih tinggi.

2. Hakikat belajar akan lebih bermakna sebab siswa dihadapkan dengan situasi dan keadaan yang sebenarnya atau bersifat alami.

3. Bahan-bahan yang dapat dipelajari lebih kaya serta lebih faktual sehingga kebenarannya lebih akurat.

4. Kegiatan belajar siswa lebih komprehensif dan lebih aktif sebab dapat dilakukan dengan berbagai cara seperti mengamati, bertanya, atau wawancara, membuktikan atau mendemonstrasikan, menguji fakta dan lain-lain.

5. Sumber belajar menjadi kaya sebab lingkungan yang dapat dipelajari bisa beraneka ragam seperti lingkungan sosial, lingkungan alam, lingkungan buatan, dan lain-lain.

6. Siswa dapat memahami dan menghayati aspek-aspek kehidupan yang ada di lingkungannya, sehingga dapat mebentuk pribadi yang tidak asing dengan kehidupan di sekitarnya serta dapat memupuk cinta lingkungan.

Berdasarkan hasil wawancara dengan beberapa guru, berbagai kendala dan hambatan yang dihadapi guru dalam mengoptimalkan lingkungan sekitar sebagai sumber pembelajaran IPS sebenarnya dapat disiasati. Sudjana (2011:215) mengemukakan terdapat beberapa prosedur yang harus ditempuh pada langkah persiapan :

1. Guru dan peserta didik menentukan tujuan pembelajaran yang diharapkan peserta didik yang berkaitan dengan penggunaan lingkungan sebagai media dan sumber belajar.

2. Tentukan objek yang harus dikunjungi dan dipelajari. Dalam menetapkan objek kunjungan tersebut hendaknya diperhatikan relevansi dengan tujuan pembelajaran, kemudahan menjangkaunya, tidak memerlukan waktu yang lama, dan keamanan bagi peserta didik.

3. Menetukan cara belajar peserta didik pada saat kunjungan dilakukan, dengan cara mencatat, mengamati suatu proses, bertanya atau wawancara atau mempraktekan/mencoba dan kegiatan lain yang dianggap perlu.

4. Guru dan peserta didik mempersiapkan perizinan jika diperlukan.

5. Persiapan teknis yang diperlukan seperti tata tertib, perlengkapan yang harus dibawa, lembar observasi dan lain sebagainya.

Dengan langkah-langkah di atas dapat diaplikasikan guru untuk meminimalisir kendala yang ditemui dalam merencanakan pemanfaatan lingkungan sekitar. Untuk kendala minimnya waktu untuk mengadakan pembelajaran di luar kelas, solusinya dengan menggabungkan materi-materi 
pembelajaran yang sesuai sehingga dengan beberapa materi pembelajaran dapat disampaikan dalam satu kali pembelajaran di luar kelas. Untuk pengelolaan peserta didik agar efektif dibagi ke dalam beberapa kelompok dengan masing-masing satu orang ketua yang bertanggung jawab terhadap anggotanya, dan peserta didik sebelum diajak keluar kelas dipersiapkan dengan materi-materi yang sesuai dengan pembelajaran sehingga mereka telah benar-benar paham baik secara fisik maupun secara keilmuan apa yang mesti mereka kerjakan di lapangan. Masalah perizinan dengan pihak sekolah perlu kepiawaian guru untuk dapat berkerjasama dengan pihak sekolah dan menjelaskan manfaat dari pembelajaran di luar kelas tanpa mengabaikan keselamatan peserta didik, ataupun berkolaborasi dengan mata pelajaran yang lain agar guru yang mengawasi dan mendampingi peserta didik seimabng jumlahnya. 